\title{
Mosaic Removal of Hedgehog Signaling in the Adult SVZ Reveals That the Residual Wild-Type Stem Cells Have a Limited Capacity for Self-Renewal
}

\author{
Francesca Balordi and Gord Fishell \\ Smilow Neuroscience Program and the Department of Cell Biology, Smilow Research Center, New York University School of Medicine, New York, New York \\ 10016
}

The Smoothened gene is necessary for cells to transduce hedgehog signaling. Although we and others have previously shown that embryonic removal of Smoothened in the neural tube results in a loss of stem cells from the postnatal subventricular zone, it was unclear whether this reflected a requirement for hedgehog signaling in the establishment or maintenance of the adult niche. Here, we have examined the consequences of conditional removal of Smoothened gene function within the subventricular zone of the adult neural stem cell niche. We observe that both proliferation and neurogenesis are compromised when hedgehog signaling is removed from subventricular zone stem cells. Moreover, even after a 10 month survival period, the stem cell niche fails to recover. It has been reported that the adult subventricular zone quickly rebounds from an antimitotic insult by increasing proliferation and replenishing the niche. During this recovery, it has been reported that hedgehog signaling appears to be upregulated. When mice in which hedgehog signaling in the subventricular zone has been strongly attenuated are given a similar antimitotic treatment, recovery is limited to the reduced level of proliferation and neurogenesis observed before the mitotic insult. Furthermore, the limited recovery that is observed appears to be largely restricted to the minority of neural stem cells that escape the conditional inactivation of Smoothened gene function. These results demonstrate that ongoing hedgehog signaling is required to maintain adult neural stem cells and that their ability to self-renew is limited.

Key words: Hh signaling; adult neural stem cells; subventricular zone; proliferation; neurogenesis; self-renewal

\section{Introduction}

Hedgehog (Hh) functions during mouse embryonic development to establish ventral patterning of the neural tube (Echelard et al., 1993; Ericson et al., 1995; Marti et al., 1995; Chiang et al., 1996; Kohtz et al., 1998; Ingham and McMahon, 2001; Rallu et al., 2002; McMahon et al., 2003; Fuccillo et al., 2004, 2006). It is also required for neural precursor proliferation (Dahmane and Ruiz i Altaba, 1999; Rowitch et al., 1999; Wallace, 1999; Wechsler-Reya and Scott, 1999; Britto et al., 2002), the maintenance of adult neural stem cells (Lai et al., 2003; Machold et al., 2003; Palma et al., 2005; Balordi and Fishell, 2007) and the migration of newborn neurons (Balordi and Fishell, 2007).

Previous work has characterized the lineage progression in the subventricular zone (SVZ) (Doetsch et al., 1997, 1999a,b, 2002; Chiasson et al., 1999). These studies have demonstrated that the periventricular slow dividing GFAP + cells (B cells) function as

Received Oct. 4, 2007; revised Nov. 7, 2007; accepted Nov. 16, 2007.

This work was supported by National Institute of Neurological Disorders and Stroke Grant R01NS039007. We thank Dr. R. Machold for making the transgenic DNA construct for the Nestin ${ }^{\text {CreER }}$ line and for conceiving the approach for targeting the adult stem cell niche. We also thank the entire Fishell laboratory and Dr. A. Joyner for helpful comments. We are grateful to Dr. A. P. McMahon for the $S m 0^{c}$ allele, Dr. A. Joyner for the Glit ${ }^{\text {Lacz }}$ allele, Dr.P.

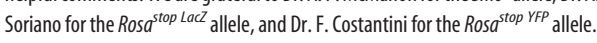

Correspondence should be addressed to Dr. Gord Fishell, Smilow Neuroscience Program and Department of Cell Biology, Smilow Research Center, New York University School of Medicine, 522 First Avenue, New York, NY 10016. E-mail: fishell@saturn.med.nyu.edu.

DOI:10.1523/JNEUROSCI.4531-07.2007

Copyright $\odot 2007$ Society for Neuroscience $\quad 0270-6474 / 07 / 2714248-12 \$ 15.00 / 0$ stem cells, which generate a transit-amplifying population (C cells) that in turn gives rise to young migrating neuroblasts (A cells). Previous studies (Machold et al., 2003; Balordi and Fishell, 2007) showed that when Smoothened (Smo), an obligate cellautonomous effector of Hh signaling (Zhang et al., 2001), is conditionally removed from neural progenitors by embryonic day 12.5 (E12.5) (using a Nestin ${ }^{C r e}$ driver line), there is no obvious effect on the SVZ at birth, suggesting that from E12.5 until birth Hh signaling is not required to maintain telencephalic progenitor proliferation. In contrast, during the first two postnatal weeks, neural progenitors within the SVZ become rapidly depleted. This suggests that after E12.5 Hh signaling is primarily important for the maintenance of the $\mathrm{B}$ cells and for regulating $\mathrm{C}$ cells proliferation. However it is still unclear whether Hh signaling is simply needed for the establishment of the adult stem cell niche or whether there is an ongoing requirement for it in the maintenance of stem cells during adulthood.

To address this question, we developed a tamoxifen-inducible Cre transgenic line (Nestin ${ }^{\text {CreERT2 }}$ ) to conditionally remove Smo function from the adult niche. In these mice, compared with tamoxifen-treated controls, we observed a marked reduction in proliferation in the adult SVZ coupled with a significant decrease in the number of both transit-amplifying cells and neuroblasts. To test whether the self-renewal property of SVZ stem cells is also affected in these mice, we used the antimitotic compound AraC to kill the rapidly dividing $\mathrm{C}$ and A cells, while sparing quiescent 
neural stem cells (B cells). We find that with removal of Smo function, B cells are severely impaired in their ability to replenish the SVZ niche. Furthermore, we show that the partial recovery that remains is mediated largely by the small fraction of SVZ progenitors that did not undergo recombination of the conditional Smo allele. These results demonstrate that adult B cells require functional Hh signaling for their maintenance. This study also reveals that wild-type stem cells have a limited ability to replenish the depleted adult SVZ niche, demonstrating that their in vivo self-renewing capacity is not unlimited.

\section{Materials and Methods}

Generation of the Nestin CreERT2 transgenic mice. We generated a transgenic mouse line that expresses the T2 mutant form of a Cre recombinase-estrogen receptor fusion $\left(C r e-E R^{T 2}\right)$ (Feil et al., 1997) under the control of the neural-specific Nestin enhancer (Zimmerman et al., 1994). We modified the pUC plasmid " 2 nd intron/TKlacZ" (Zimmerman et al., 1994), in which the $1.8 \mathrm{~kb}$ genomic BstYI fragment containing nestin's second intron (rat) is inserted on the $5^{\prime}$ side of a 160 bp herpes simplex virus TK promoter, followed by the lac $\mathrm{cDNA}$ and by a $250 \mathrm{bp}$ SV40 polyA site. We subcloned the $2 \mathrm{~kb} E c o$ RI fragment of the pCre$\mathrm{ER}^{\mathrm{T} 2}$ [also called pCre-ER(AA2)] vector (Feil et al., 1997) (kind gift from P. Chambon, Institut de Génétique et de Biologie Moléculaire et Cellulaire, Illkirch, France), containing the Cre-ER ${ }^{\mathrm{T} 2} \mathrm{cDNA}$, in the pUC plasmid " 2 ndintron/TKlacZ," replacing the lacZ cDNA. To remove the pUC vector sequences for pronuclear injection, the plasmid was digested with SmaI and the insert was isolated by agarose gel electrophoresis. The entire Nestin ${ }^{\text {CreERT2 }}$ transgene $(4.2 \mathrm{~kb})$ was purified and injected into the pronuclei of fertilized one-cell eggs from FVB/N strain. Potential founder animals were screened by PCR for Cre with the following primers: forward primer 5' $5^{\prime}$-TAAAGATATCTCACGTACTG-3' and reverse $5^{\prime}$ TCTCTGACCAGAGTCATCCT- $3^{\prime}$. The size of the PCR product is 280 bp. We generated four founder Nestin ${ }^{C r e E R}$ lines, all of which had CreER expression that resembled the endogenous pattern of Nestin expression (data not shown). The transgenic line we ultimately selected to use in these experiments had an intermediate level of expression, as the strongest expressing line had a high degree of nonregulated recombination.

Reporter strains used. Rosa ${ }^{\text {stop LacZ/+ }}$ mice reporter mice were the generous gift from P. Soriano (Fred Hutchinson Cancer Research Center, Seattle, WA) and genotyped as described previously (Soriano, 1999). $\operatorname{Rosa}^{\text {stop } Y F P /+}$ reporter mice were the generous gift from F. Costantini (Columbia University Medical Center, New York, NY) and genotyped as described previously (Srinivas et al., 2001). Gli1 ${ }^{\text {LacZ/+ }}$ mice were the generous gift from A. Joyner (Sloan-Kettering Institute, New York, NY) (Bai et al., 2002) and, when crossed to the conditional Smo mice, were genotyped with the following primers that recognize the LacZ from the Gli1 locus: forward primer 5'-CCAGTTTCTGAGATGAGGGTTAGAGGC-3' and reverse $5^{\prime}$-ACGACTGTCCTGGCCGTAACCGACCC-3'. The size of the PCR product is $850 \mathrm{bp}$.

Mice breedings. Mice were maintained and killed in accordance with the protocols approved by the Institutional Animal Care and Use Committee at the New York University School of Medicine.

The Nestin ${ }^{\text {CreER }}$ allele was first crossed to Rosa $a^{\text {stop LacZ/+ }}$ mice reporter mice to test the functionality of the CreER-mediated recombination induced after tamoxifen treatment and to assess the degree of background recombination, in absence of tamoxifen. The Nestin ${ }^{\text {CreER }}$ allele was also crossed to Rosa $a^{\text {stop } Y F P /+}$ reporter mice to assess whether cells undergoing recombination within the SVZ and SGL corresponded to proliferating cells.

Conditional (floxed) Smo mice $\left(S m o^{c / c}\right)$ were a gift from Andrew McMahon (Harvard University, Cambridge, MA) and were genotyped as described previously (Lewis et al., 2001; Long et al., 2001).

Mutant mice (Nestin ${ }^{\mathrm{CreER} /+} ; \mathrm{Smo}^{c / c}$ ) were obtained by crossing homozygous conditional Smo mice $\left(S m o^{c / c}\right)$ with mice homozygous for the conditional Smo allele and heterozygous for the Nestin ${ }^{\text {CreER }}$ allele $\left(\mathrm{Nestin}^{\mathrm{CreER} /+} ; \mathrm{Smo}^{c / c}\right)$. We also generated mutant mice carrying the Gli1 $^{\text {LacZ }}$ allele (Nestin ${ }^{\mathrm{CreER} /+} ; \mathrm{Smo}^{c / c}$; $\mathrm{Glil}^{\mathrm{LacZ/+}}$ ) by crossing mice homozygous for the conditional Smo allele and heterozygous for the Gli $^{\text {LacZ }}$ allele $\left(\mathrm{Smo}^{c / c}\right.$; Gli1 $\left.{ }^{\text {LacZ/+ }}\right)$ with mice homozygous for the conditional Smo allele and heterozygous for the Nestin CreER allele $\left(\mathrm{Nestin}^{\mathrm{CreER} /+} ; \mathrm{Smo}^{c / c}\right)$. We also generated mutant mice carrying the Rosa $^{\text {stop LacZ/+ }}$ allele (Nestin ${ }^{\mathrm{CreER} /+} ; \mathrm{Smo}^{\text {c/c }} ;$ Rosa $^{\text {stop LacZ/++}}$ ) by crossing mice homozygous for the conditional Smo allele and for the Rosa $a^{\text {stop LacZ }}$ allele $\left(S m o^{c / c} ; R_{\text {Rosa }}{ }^{\text {stop LacZ/LacZ }}\right)$ with mice heterozygous for the conditional Smo allele and for the Nestin ${ }^{\mathrm{CreER}}$ allele $\left(\mathrm{Nestin}{ }^{\mathrm{CreER} /+} ; \mathrm{Smo}^{c /+}\right)$.

Tissue preparation. Embryos collected for analysis were briefly fixed in $4 \%$ paraformaldehyde (PFA) in PBS, washed in PBS, and equilibrated in $30 \%$ sucrose/PBS before mounting in TissueTek (VWR, West Chester, PA) on dry ice and cut on a Zeiss (Thornwood, NY) HM500 OM cryostat.

Adult mice were overdosed with anesthetic and transcardially perfused. Brains were removed and postfixed with $4 \%$ PFA in PBS. For frozen sections $(12-20 \mu \mathrm{m})$, brains were washed in PBS, cryoprotected in $30 \%$ sucrose/PBS, embedded in Tissue-Tek (VWR) on dry ice and cut on a Zeiss HM500 OM cryostat. For free floating sections $(80 \mu \mathrm{m})$, brains were washed in PBS and cut on a Leica (Bannockburn, IL) Vibratome 1000S.

Tamoxifen and bromodeoxyuridine administration. Tamoxifen (Sigma, St. Louis, MO) was prepared as a $25 \mathrm{mg} / \mathrm{ml}$ stock solution in corn oil (C-8267; Sigma) and was administrated either via oral gavage (only in Fig. 3) or intraperitoneal injections (in all other figures). Bromodeoxyuridine (BrdU; Sigma) was administrated intraperitoneally at 100 $\mathrm{mg} / \mathrm{g}$ of body weight.

For embryonic analysis of Nestin ${ }^{\mathrm{CreER} /{ }^{+}}$;Rosa ${ }^{\text {stop LacZ/+ }}$ mice (see Fig. $2 b$ ) one dose of $5 \mathrm{mg}$ tamoxifen/35 g mouse was administered by intraperitoneal injection to the pregnant mouse at midday of the embryonic stage E12.5 (midday of the observed plug was considered $0.5 \mathrm{~d}$ postcoitus). Embryos were collected for analysis $1 \mathrm{~d}$ later.

For short-term adult analysis of Nestin ${ }^{\mathrm{CreER} /+} ; \mathrm{Ros}^{\text {stop LacZ/+ }}{ }^{\text {mice (see }}$ Fig. $2 d$ ) $5 \mathrm{mg} / 35 \mathrm{~g}$ mouse were administered daily by intraperitoneal injection for three consecutive days and killed on the fourth day. For long-term adult analysis of Nestin ${ }^{\mathrm{CrEER} /+_{+}} ; \mathrm{Rosa}^{\text {stop LacZ/+ }}$ mice (see Fig. 3) one dose of $10 \mathrm{mg} / 35 \mathrm{~g}$ mouse was administered by oral gavage at P120 and mice were analyzed $3 \mathrm{~d}, 1$ week, 1 month and 2 months later.

For adult analysis of Nestin ${ }^{\mathrm{CrERR} /+}$;Rosa ${ }^{\text {stop } \mathrm{YFP} /+}$ mice (see Fig. 4), 5 $\mathrm{mg} / 35 \mathrm{~g}$ of mouse was administered daily by intraperitoneal injection for 3 consecutive days. After $15 \mathrm{~d}$, these tamoxifen-treated Nestin ${ }^{\mathrm{CreR}^{\prime}+}$; Rosa $a^{\text {stop } Y F P /+}$ mice were intraperitoneally injected with BrdU three times a day (morning, afternoon, evening) for 2 consecutive days and killed the morning of the third day.

For adult analysis of $\mathrm{Nestin}^{\mathrm{CreER} /+} ; \mathrm{Smo}^{c / c}$ mice, Nestin ${ }^{\mathrm{CreER} /+} ; \mathrm{Smo}^{\mathrm{clc}}$; Glil $^{\text {LacZ/+ }}$ mice and Nestin ${ }^{\text {CreER/+ }} ;$ Smo $^{\text {c/c }} ;$ Rosa $^{\text {stop lacZ/+ }}$ mice, $5 \mathrm{mg} / 35 \mathrm{~g}$ mouse was administered by intraperitoneal injection every other day for a total of eight injections. After a short break of 1-2 weeks, another round of eight injections was administered. For BrdU pulse-kill experiment, these tamoxifen-treated mice (i.e., Nestin ${ }^{\mathrm{CreER} /+} ; \mathrm{Smo} \mathrm{o}^{c / c}$ mice, $\mathrm{Nestin}^{\mathrm{CreER} /{ }^{+}} ; \mathrm{Smo}^{c / c}$; $\mathrm{Glil}^{\mathrm{LacZ} /+}$ mice and $\mathrm{Nestin}^{\mathrm{CreER} /+} ; \mathrm{Smo}^{c / c}$; Rosa $^{\text {stop lacz/+ }}$ mice) were intraperitoneally injected with BrdU three times a day (morning, afternoon, evening) for 2 consecutive days and killed the morning of the third day (see Fig. $5 a$ ). Both tamoxifen and BrdU treatments were performed in parallel on respective control animals (i.e., Smo ${ }^{c / c}$ mice, Smo ${ }^{c / c}$; Gli ${ }^{\mathrm{LacZ}^{++}}$mice and Nestin $\mathrm{CreER/+}^{\text {; }}$ Smo ${ }^{c /+}$; Rosa $^{\text {stop lacZ/+ }}$ mice). We found that it was necessary to administer 16 treatments with tamoxifen to obtain a high degree of Smo recombination. To arrive at this dosage, we tried a variety of milder regimes that proved ineffective in impairing Hh signaling assessed on the basis of Gli1 $^{\text {LacZ/+ }}$ reporter expression. Notably, the high level of tamoxifen exposure in our experiments, even in $\mathrm{Nestin}^{\mathrm{CreER} /+} ; \mathrm{Smo}^{\text {c/+ }} ;$ Rosa $^{\text {stop lacZ/+ }}$ mice, did not have an appreciable short or long-effect on proliferation in the SVZ (Martinez-Cerdeno et al., 2006).

Immunocytochemistry. Vibratome free floating sections or cryostat frozen sections were stained with the following primary antibodies: mouse $\alpha$-BrdU (1:100; BD Biosciences, San Jose, CA), rabbit $\alpha$-green fluorescent protein (GFP; 1:1000; Millipore, Billerica, MA), mouse $\alpha$-Mash-1 (1:500; BD Biosciences), goat $\alpha$-doublecortin (Dcx; C-18; 1:1000; Santa Cruz Biotechnology, Santa Cruz, CA), rabbit $\alpha$-GFAP (1: 2000; Accurate Chemical, Westbury, NY), rabbit $\alpha$-cleaved caspase-3 (1:200; Cell Signaling Technology, Beverly, MA). Secondary antibodies, raised in donkey, used at 1:1000 (Alexa 594 and Alexa 488) were obtained from Invitrogen (Eugene, OR). 
Standard immunocytochemical staining procedures were used. For BrdU staining, sections were treated with $\mathrm{HCl} 1 \mathrm{~N}$ for 15 min at $55^{\circ} \mathrm{C}$, washed with $\mathrm{PBS}$, treated with Proteinase $\mathrm{K}$ for $10 \mathrm{~min}$ at $37^{\circ} \mathrm{C}$, washed with PBS, postfixed with $4 \%$ PFA for $10 \mathrm{~min}$ at room temperature (RT), washed with PBS, before proceeding to the blocking step.

Fluorescent images were obtained using an Axioplan (Zeiss) and MetaMorph software (Universal Imaging, Downingtown, PA). Confocal imaging was done on a LSM 510 Axioplan 2 Imaging (Zeiss). Optical sections were taken every $1 \mu \mathrm{m}$.

Whole mounts of the lateral wall of the lateral ventricle. Adult [postnatal day 60 (P60)] mice Gli $^{\text {LacZ/+ }}$ were perfused intracardially with $0.9 \%$ saline and their brains were removed. The lateral walls of the lateral ventricle were dissected and the resulting whole mounts were fixed overnight in 4\% PFA. After some washes in PBS, whole mounts were immersed in $100 \%$ methanol and $100 \%$ acetone for 30 min each at $-20^{\circ} \mathrm{C}$. Whole mounts were washed three times in $\mathrm{PBS} / 0.5 \%$ Triton $\mathrm{X}-100$, blocked in $10 \%$ donkey serum/PBS/0.5\% Triton X-100 for $2 \mathrm{~h}$ at RT, incubated for $48-72 \mathrm{~h}$ at $4^{\circ} \mathrm{C}$ with 1:1000 goat anti-Dcx antibody (C-18; Santa Cruz Biotechnology) in PBS/0.5\% Triton X-100 and revealed with a secondary anti-goat peroxidase-coupled antibody (1:500; Vector Laboratories, Burlingame, CA). The staining was visualized with $0.02 \%$ diaminobenzidine (Vector Laboratories) in phosphate buffer $(0.1 \mathrm{M}, \mathrm{pH}$ 7.4) and $0.01 \% \mathrm{H} 2 \mathrm{O} 2$. Images were obtained by bright-field photography on a Zeiss Axioskop using Spot Advanced software.

In situ hybridization. mRNA in situ hybridizations was performed as described previously (Wilkinson and Nieto, 1993). RNA probes were labeled with digoxigenin and visualized with BM-Purple, according the manufacturer's instruction (Roche Biosciences, Palo Alto, CA). The cRNA probes used included Cre (kindly provided by A. Joyner) and Nestin.

To generate Nestin probes we linearized the IMAGE EST clone (6405026; Invitrogen) with BamHI and used T3 RNA polymerase to obtain antisense probe, alternatively we linearized with AseI or DraI and used T7 RNA polymerase to obtain sense probe.

Images were obtained by bright-field photography on a Zeiss Axioskop using Spot Advanced software.

$\beta$-Galactosidase staining. Tissue sections were stained for $\beta$-galactosidase ( $\beta$-Gal) histochemistry using a solution containing: 0.1 M phosphate buffer, $2 \mathrm{~mm} \mathrm{MgCl}_{2}, 0.01 \%$ sodium deoxycholate, $0.02 \%$ $\left.\mathrm{NP}-40,5 \mathrm{~mm} \mathrm{~K}_{3} \mathrm{Fe}(\mathrm{CN})_{6}, 5 \mathrm{~mm} \mathrm{~K} \mathrm{Fe}_{4} \mathrm{FN}\right)_{6}$, and $1 \mathrm{mg} / \mathrm{ml} \mathrm{X-Gal} \mathrm{(5-}$ (bromo-4-chloro-3-indolyl- $\beta$-D-galactopyranoside; Fisher Scientific, Hampton, NH) at RT overnight. Stained tissue sections were then washed in PBS, counterstained with Fast Red, dehydrated, and coverslipped with Permount before brightfield photography on a Zeiss Axioskop using Spot Advanced software.

Cell dissociation and in vitro culturing. The telencephalic SVZ was dissected from adult Nestin ${ }^{\mathrm{CreER} /{ }^{+}} ; \mathrm{Smo}^{c / c}$ and control $\left(\mathrm{Smo}^{c / c}\right)$ animals. Specifically, the SVZ was dissected away from postmitotic tissues using Lumsden bioscissors. The tissue to be dissociated was collected, minced, and incubated in papain (20 U/ml in EBSS, 1 mm cysteine, $0.5 \mathrm{~mm}$ EDTA) (Worthington Biochemical, Lakewood, NJ) at $37^{\circ} \mathrm{C}$ for $1 \mathrm{~h}$. Ovomucoid inhibitor and albumin (both $10 \mathrm{mg} / \mathrm{ml}$ ) were used to inhibit papain and $100 \mathrm{U} / \mathrm{ml}$ DNase was included. Samples were triturated using a firepolished Pasteur pipette. Cells were washed twice and resuspended in DMEM/F12 media (Invitrogen). Cells were transferred to 6-well dishes and cultured at clonal density $(<1-2$ cells/ $\mu \mathrm{l})$ in DMEM/F12 media containing B27 supplement (Invitrogen), 2 mm glutamine (Invitrogen), $2 \mu \mathrm{g} / \mathrm{ml}$ heparin (Sigma), $2 \mathrm{~mm}$ pen/strep (Invitrogen), $20 \mathrm{ng} / \mathrm{ml} \mathrm{FGFb}$ (fibroblast growth factor basic) (Invitrogen), and $20 \mathrm{ng} / \mathrm{ml} \mathrm{EGF} \mathrm{(epider-}$ mal growth factor) (Invitrogen). Primary neurospheres were isolated after 7-10 d of culture (Reynolds and Weiss, 1992). These were then counted and collected individually for PCR analysis.

PCR genotyping of neurospheres. To detect the presence of the recombined allele we used the following primers: forward primer $5^{\prime}$ GGCCTGCGCTGCTCAACATGG-3' and reverse primer 5' -CCATCACGTCGAACTCCTGGC- $3^{\prime}$. The size of the PCR product is $350 \mathrm{bp}$.

To detect the presence of the floxed allele (not recombined) we used the following primers: forward primer 5'-CCACTGCGAGCCTTTGCGCTAC-3' and reverse primer 5'-GGCGCTACCGGTGGATGTGG$3^{\prime}$. The size of the PCR product is $350 \mathrm{bp}$.

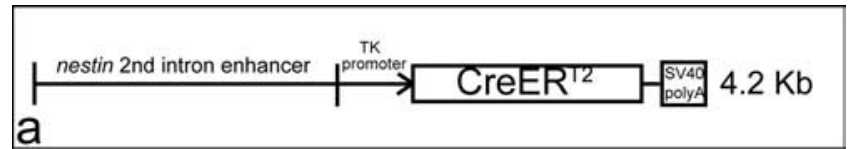

a
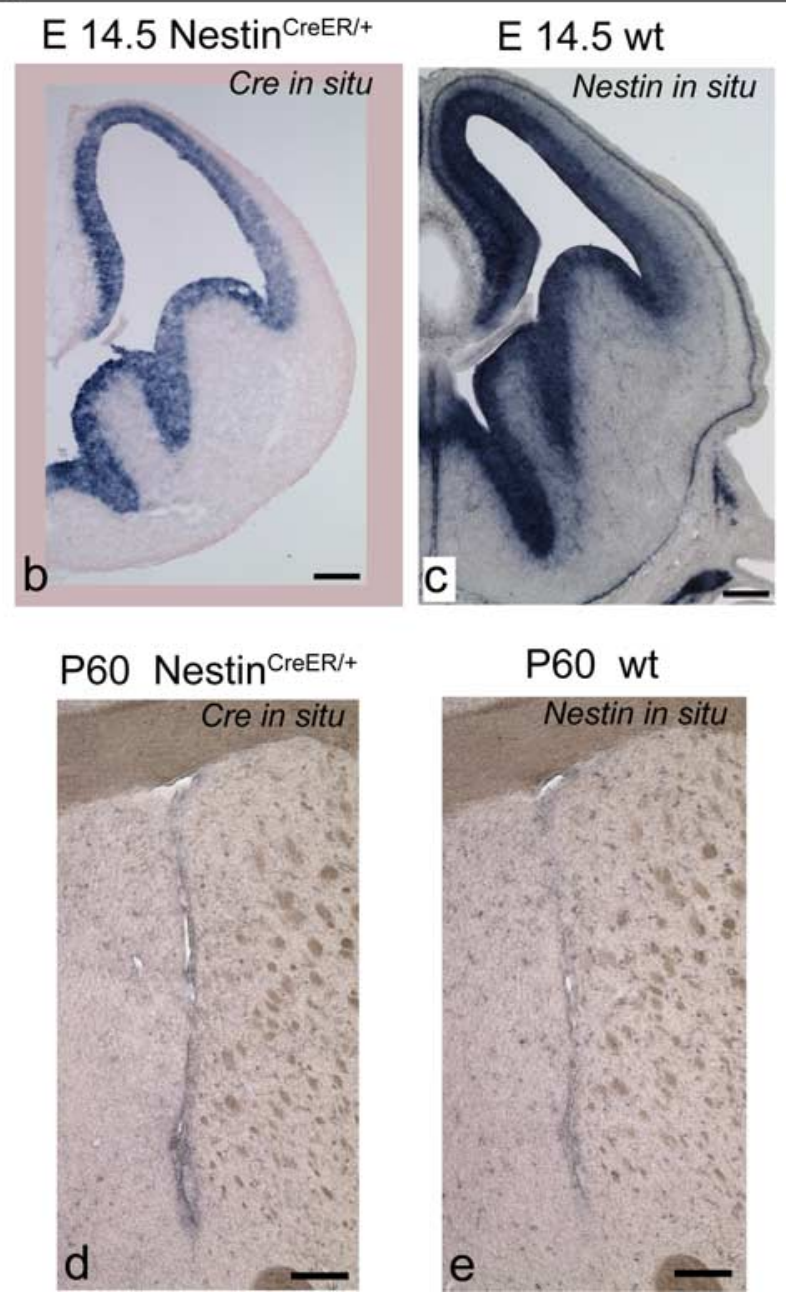

Figure 1. Generation of the Nestin ${ }^{\text {CreERT2 }}$ transgenic mouse line. $\boldsymbol{a}$, Scheme of the transgenic construct used to make the line. $\boldsymbol{b}-\boldsymbol{e}$, Coronal views of the embryonic $(\boldsymbol{a}, \boldsymbol{c})$ and adult $(\boldsymbol{d}, \boldsymbol{e})$ SVZ showing the pattern of expression of the transgene by Cre in situ hybridization $(\boldsymbol{b}, \boldsymbol{d})$, compared with the expression pattern of Nestin $(\boldsymbol{c}, \boldsymbol{e})$. Scale bars: $200 \mu \mathrm{m}$.

Infusions. Cytosine- $\beta$-D-arabinofuranoside ( $4 \%$ AraC; Sigma) in vehicle $(0.9 \%$ saline $)$ or vehicle alone was infused onto the surface of the brain of adult mice (4 months old) with a mini-osmotic pump (Alzet, Palo Alto, CA, model 1007D; flow rate $0.5 \mu \mathrm{l} / \mathrm{hr}, 7 \mathrm{~d}$ ). Cannulas were implanted stereotaxically onto the surface of the brain at the following coordinates: anterior (A), $1 \mathrm{~mm}$; lateral (L), $0 \mathrm{~mm}$; depth (D), $0.1 \mathrm{~mm}$ (relative to Bregma and the surface of the brain). This treatment produced no lesion on the ventricular cavities or in the SVZ. After $6 \mathrm{~d}$ of infusion, the pump was removed and mice were killed at the indicated survivals $[n$ (mice) $=3$ for each survival $]$.

Quantitation. Using MetaMorph software (Universal Imaging) the number of BrdU, $\beta$-Gal and Mash1 positive cells was counted in the SVZ. Three to five sections were analyzed per animal with a minimum of three animals.

Microsoft (Redmond, WA) Excel was used to compute the data and perform the statistical analyses.

Student's $t$ test (one-tailed) was performed to calculate $p$ values and to determine whether the results were significantly different.

\section{Results}

Generation of a Nestin ${ }^{\mathrm{CreERT2}}$ transgenic mouse line

We generated a transgenic mouse line that expresses Cre-ER $R^{T 2}$

(Feil et al., 1997) under the control of the neural-specific Nestin 

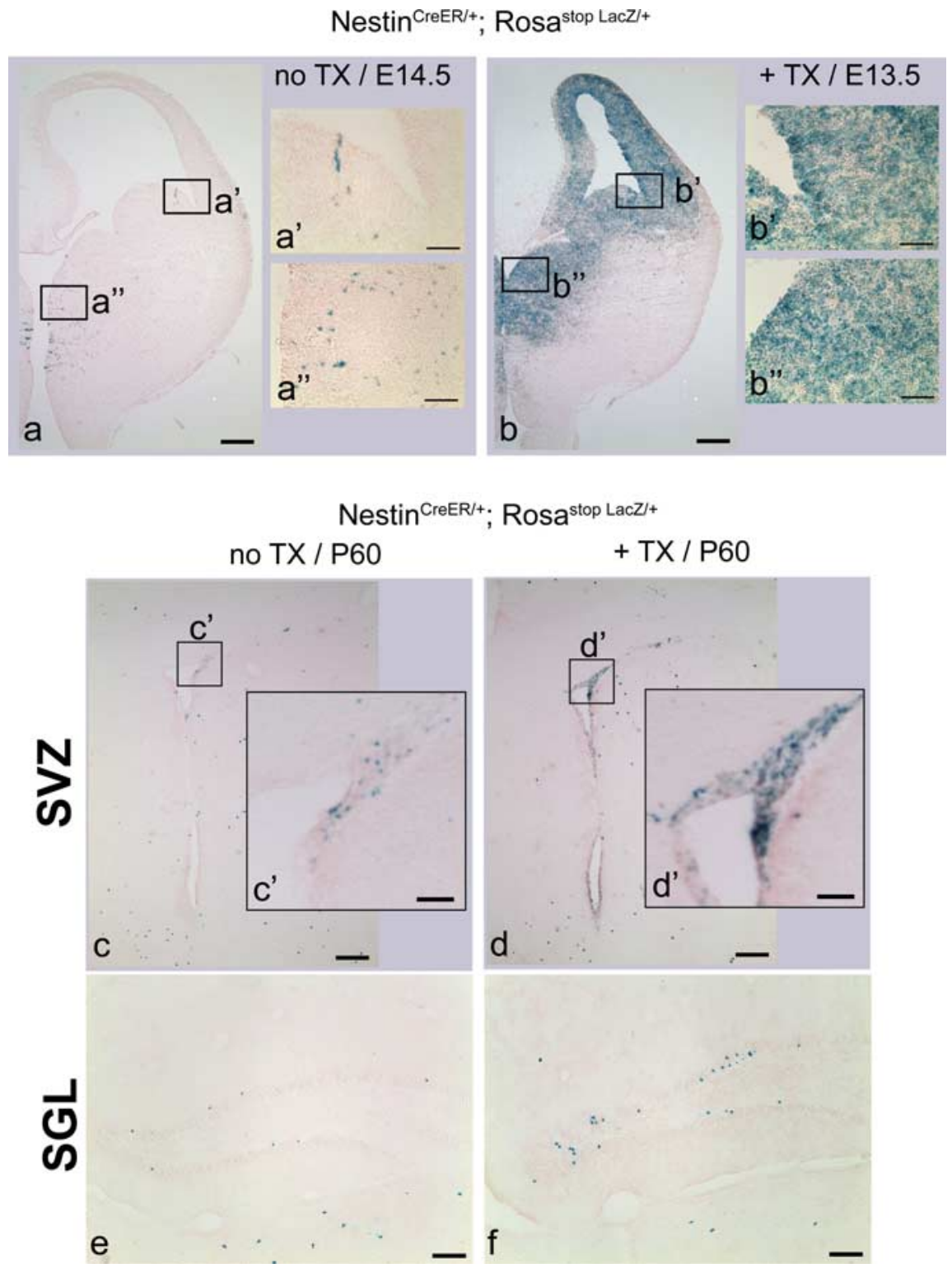

Figure 2. Tamoxifen can efficiently induce Cre recombinase activity in the SVZ and in the SGL in adulthood. $\boldsymbol{a}-\boldsymbol{f}$, Coronal views of the embryonic $(\boldsymbol{a}, \boldsymbol{b})$ and adult $(\boldsymbol{c}, \boldsymbol{d})$ SVZ and the adult SGL $(\boldsymbol{e}, \boldsymbol{f})$ showing $\beta$-Gal staining representing the expression of LacZ, in Nesti ${ }^{\text {(reeR/++ }}$; Rosa $a^{\text {stop LacZ/+ }}$ mice not treated with tamoxifen $(\boldsymbol{a}, \boldsymbol{c}, \boldsymbol{e})$, and in Nestin ${ }^{\text {(reER/++ }}$; Rosa $a^{\text {stop LacZ/+ }}$ mice treated with tamoxifen $(\boldsymbol{b}, \boldsymbol{d}, \boldsymbol{f})$. For embryonic analysis, tamoxifen was administrated once at $\mathrm{E} 12.5$ and analysis was done $1 \mathrm{~d}$ later $(\boldsymbol{b})$. For adult analysis, tamoxifen was administrated at $\mathrm{P} 60$ for 3 consecutive days and analysis was done $1 \mathrm{~d}$ later $(\boldsymbol{d}, \boldsymbol{f})$. Scale bars: $\boldsymbol{a}-\boldsymbol{d}$, $200 \mu \mathrm{m} ; \boldsymbol{e}, \boldsymbol{f}, 100 \mu \mathrm{m} ; \boldsymbol{a}^{\prime}-\boldsymbol{d}^{\prime \prime}, 50 \mu \mathrm{m}$.

enhancer (Zimmerman et al., 1994). We analyzed the pattern of expression of the transgene by in situ hybridization for Cre mRNA and compared it to the expression pattern of Nestin, in the subventricular zone. We found that transgenic Cre-ER ${ }^{T 2}$ expression faithfully mirrored Nestin expression both embryonically and in adulthood (Fig. 1).

We then tested the fidelity and functionality of the inducible Cre activity by crossing transgenic Nestin ${ }^{\text {CreER }}$ mice to Rosa-26 reporter mice (Rosastop LacZ/+ mice), which have a loxP-flanked stop cassette followed by the lacZ gene in the Rosa-26 locus (Soriano, 1999). We observed that our transgenic line showed a relatively low rate of spontaneous recombination without tamoxifen induction, both embryonically and in adulthood (Fig. $2 a, c, e)$. In contrast, lacZ was broadly expressed in the SVZ of tamoxifen-treated embryos and tamoxifen-treated adult ani- mals, indicating that tamoxifen can efficiently induce Cre recombinase activity in the SVZ at both ages (Fig. $2 b, d$ ). We also observed Cre activity induction in the adult SGL (Fig. 2f).

Throughout adult life new neurons are continuously produced from the SVZ germinal centers and migrate through the rostral migratory stream (RMS) (Lois and Alvarez-Buylla, 1994; Lois et al., 1996) to reach their final destination, the olfactory bulb (OB) (Altman, 1969). To test whether our transgenic approach could be used to visualize this continual production of new neurons, we gave one dose of tamoxifen to 4-month-old Nestin ${ }^{\mathrm{CreER} /+} ;$ Rosas $^{\text {stop LacZ/+ }}$ mice and analyzed brains $3 \mathrm{~d}, 1$ week, 1 month, and 2 months later. We observed a progressive increase over time in the number of $\beta-\mathrm{Gal}^{+}$cells around the lateral ventricle, along the RMS and in the OB, as would be expected for postnatal SVZ neurogenesis (Fig. 3a-l). Another germinal center where new neurons are continuously added throughout adulthood is the subgranular layer (SGL) of the hippocampal dentate gyrus (Stanfield and Trice, 1988; Markakis and Gage, 1999): we also detected a progressive increase over time in the number of $\beta$-Gal ${ }^{+}$cells in the SGL (Fig. $3 m-p)$ after the initial labeling. To confirm whether cells undergoing recombination within the SVZ and SGL corresponded to proliferating progenitors and neuroblasts, we injected Nestin ${ }^{\mathrm{CreER} /+}$; Rosatop YFP/+ mice with tamoxifen at P60 and $15 \mathrm{~d}$ later we BrdU-pulsed the mice for 2 consecutive days before they were killed. We observed that BrdU colocalized with YFP+ (yellow fluorescent protein positive) cells within the SVZ (Fig. 4a) and SGL (Fig. 4b) adult neurogenic niches.

\section{Loss of Hh signaling in Nestin ${ }^{\mathrm{CreER}}$; Smo ${ }^{c / c}$ mice in the adult SVZ \\ We then made use of the conditional Smo null allele $\left(S m o^{c / c}\right)$, in conjunction with this Nestin ${ }^{\mathrm{CreER} /+}$ driver mouse line to generate} Smo conditional mutants that have functional Hh signaling until tamoxifen is administered. Before treating these animals with tamoxifen, we wanted to confirm that the relatively low level of background recombination in Nestin ${ }^{\text {CreER/+ }}$ mice (observed with the reporter allele Rosastop LacZ/+ ) (Fig. 2c) was insufficient to cause an Hh signaling loss of function phenotype. To assess this, we took advantage of the $\mathrm{Gli}^{\mathrm{Lac} Z}$ allele, which provides a readout of the Hh pathway (Lee et al., 1997; Bai et al., 2002, 2004). We compared tamoxifen-untreated Nestin ${ }^{\mathrm{CreER} /+} ; \mathrm{Smo}^{c^{c / c}}$; Gli1 ${ }^{\mathrm{LaCZ} /+}$ mice to $S m o^{c / c} ; G l i l^{\text {LacZ/+ }}$ mice and did not observe any difference in LacZ expression, as assessed through $\beta$-Gal histochemistry (supplemental Fig. $1 a-c$, available at www.jneurosci.org as supplemental material). Moreover no difference was observed in the general level of proliferation in the SVZ in vivo (supplemental Fig. $1 d-f$, available at www.jneurosci.org as supplemental material) 
and in the ability of the SVZ progenitors to give rise to neurospheres in vitro (supplemental Fig. 1g, available at www. jneurosci.org as supplemental material). When we treated Nestin ${ }^{\mathrm{CreER} /+}$; Smo ${ }^{\mathrm{clc}}$; $\mathrm{Gli1}^{\mathrm{LacZ/+}}$ animals with tamoxifen starting at P60 (Fig. 5a), we observed that Hh signaling was greatly reduced (by $72 \%$ ), based on visualization of $\beta$-Gal histochemical staining (Fig. $5 b-d$ ). To obtain a more direct assessment of the degree of recombination at the Smo locus in tamoxifen-treated $\mathrm{Nestin}^{\mathrm{CreER} /+}$; Smo ${ }^{c / c}$ mice, we dissociated the SVZ from these mice and grew them under in vitro conditions that promoted neurosphere formation. Based on PCR genotyping performed on individual neurospheres obtained from these mice, in $70 \%$ of cases genomic recombination of both conditional alleles of Smo were deleted (Fig. 5e). Together, these data clearly show that tamoxifen treatment of the Nestin ${ }^{\mathrm{CreER} /+}$; Smo ${ }^{c / c}$ mice, successfully removes most of the $\mathrm{Hh}$ signaling in the SVZ in adulthood.

\section{Removal of Hh signaling in adulthood results in reduced proliferation and decreased production of newborn neuroblasts}

We detected a marked (60\%) reduction in proliferation in the SVZ of tamoxifentreated $\mathrm{Nestin}^{\mathrm{CreER} /+}$; Smo ${ }^{c / c}$ mice compared with tamoxifen-treated $S m o^{c / c}$ controls (Fig. $5 f-h$ ). Indeed, this mutant phenotype closely resembles that observed in our previous analyses (Machold et al., 2003; Balordi and Fishell, 2007), where Smo gene function in the niche was removed by E12.5. In addition Nestin ${ }^{\mathrm{CreER} /+} ; \mathrm{Smo}^{\mathrm{c} / \mathrm{c}}$ progenitors from the SVZ gave rise to fewer neurospheres $(70 \%$ reduction) than controls (Fig. 5i), again similar to our previous analysis (Machold et al., 2003). Because the neurosphere assay is a measure of type C cells (Doetsch et al., 2002), this result is consistent with the reduction in general proliferation assessed by BrdU pulse (Fig. $5 f-h$ ). We also observed that in tamoxifentreated Nestin ${ }^{\mathrm{CreER} /+}$; Smo ${ }^{c / c}$ mice, the expression of Mash1 (C cell marker) (Parras et al., 2004), Dcx (A cell marker) (Francis et al., 1999; Gleeson et al., 1999; Englund et al., 2002; Brown et al., 2003; Yang et al., 2004) and GFAP (B cell marker, but also marker of mature astrocytes; Doetsch et al., 1997,1999a,b) is reduced (Fig. 6). The striking reduction in GFAP staining in tamoxifentreated Nestin $\mathrm{CreER/+}^{+} \mathrm{Smo}^{c / c}$ mice compared with controls suggests that Hh signaling removal has a direct effect on $\mathrm{B}$ cells. However, unlike Nestin ${ }^{\mathrm{Cre} /+} ; \mathrm{Smo}^{c / c}$ mice, we did not observe differences in cell death in the SVZ of tamoxifen-treated $\mathrm{Nestin}^{\mathrm{CreER} /+}$; Smo ${ }^{\text {c/c }}$ mice and controls, based on Caspase-3 staining (data not shown).

We find that adult neurogenesis can be cumulatively visualized in tamoxifen-treated Nestin ${ }^{\mathrm{CreER} /+} ; \mathrm{Rosa}^{\text {stop LacZ/+ }}$ mice (Fig. 3). Hence, by crossing the reporter allele Rosa $a^{\text {stop LacZ/+ }}$ onto a Nestin ${ }^{\mathrm{CreER} /+} ; \mathrm{Smo}^{c / c}$ background, it is possible to directly demonstrate that the continual production of neuroblasts is impaired when Smo gene function is compromised in the SVZ. These con-

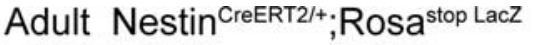
1 week $\quad 1$ month

2 months

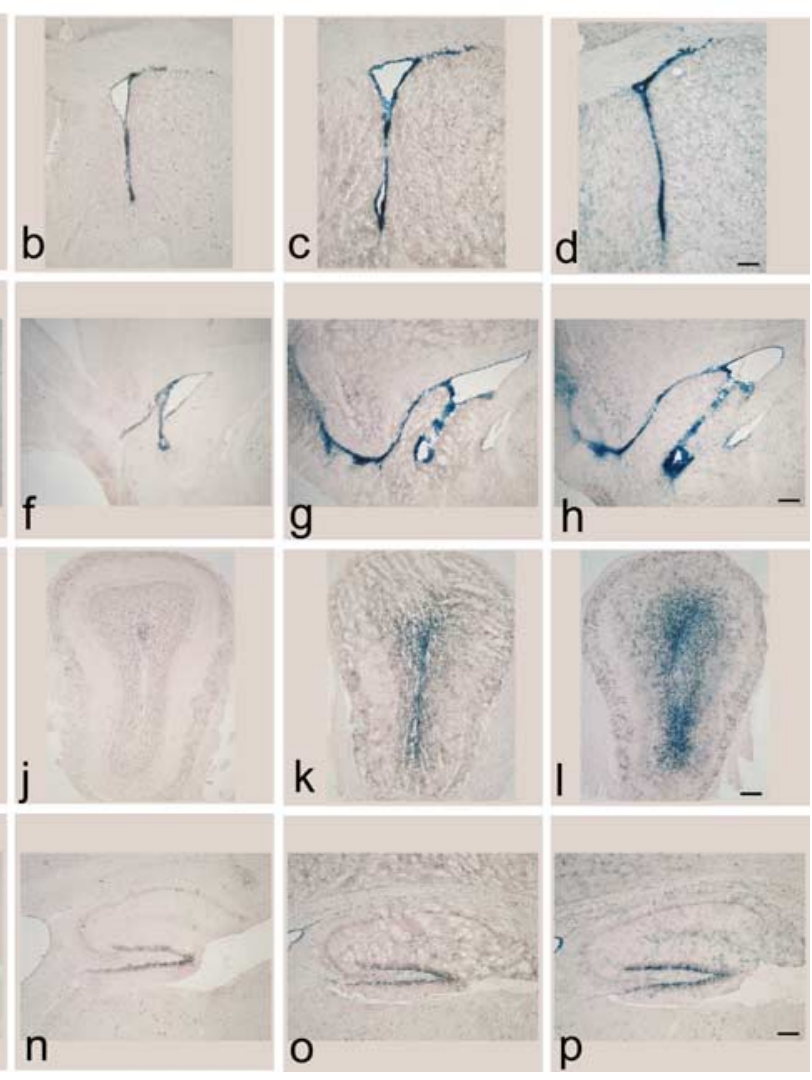

n

O

Figure 3. Our Nestin ${ }^{\text {CreERT2 }}$ transgenic line can be used to visualize the continual production of new neurons, throughout adult life, in the germinal centers. $\boldsymbol{a}-\boldsymbol{p}$, Coronal $(\boldsymbol{a}-\boldsymbol{d}, \boldsymbol{i}-\boldsymbol{I})$ and sagittal $(\boldsymbol{e}-\boldsymbol{h}, \boldsymbol{m}-\boldsymbol{p})$ views of the adult SVZ $(\boldsymbol{a}-\boldsymbol{d})$, RMS $(\boldsymbol{e}-\boldsymbol{h})$, OB $(\boldsymbol{i}-\boldsymbol{I})$, and SGL $(\boldsymbol{m}-\boldsymbol{p})$ showing $\beta$-Gal staining representing the expression of LacZ, in Nestin ${ }^{\text {CreER/+ }} ;$ Ros $a^{\text {stop LacZ/+ }}$ mice treated once with tamoxifen at P120 and analyzed 3 d later $(\boldsymbol{a}, \boldsymbol{e}, \boldsymbol{i}, \boldsymbol{m}), 1$ week later $(\boldsymbol{b}, \boldsymbol{f}, \boldsymbol{j}, \boldsymbol{n}), 1$ month later $(\boldsymbol{c}, \boldsymbol{g}, \boldsymbol{k}, \boldsymbol{o})$, and 2 months later $(\boldsymbol{d}, \boldsymbol{h}, \boldsymbol{i}, \boldsymbol{p})$. Scale bars: (in $\boldsymbol{d}, \boldsymbol{I}, \boldsymbol{p}) \boldsymbol{a}-\boldsymbol{d}, \boldsymbol{i}-\boldsymbol{p}, 200 \mu \mathrm{m}$; (in $\boldsymbol{h}) \boldsymbol{e}-\boldsymbol{h}, 400 \mu \mathrm{m}$.

ditional Smo mutants (i.e., Nestin ${ }^{\mathrm{CreER} /+} ; \mathrm{Smo}^{c / c} ; \mathrm{Rosa}^{\text {stop LacZ/+}}$ ) compared with controls (i.e., tamoxifen-treated Nestin ${ }^{\mathrm{CreER} /+}$; $\mathrm{Smo}^{\mathrm{c/+}} ; \mathrm{Rosa}^{\text {stop LacZ/+ }}$ mice) show a reduced number of $\beta-\mathrm{Gal}^{+}$ cells around the SVZ, along the RMS and in the OB (supplemental Fig. 2, available at www.jneurosci.org as supplemental material). As expected, conditionally Smo compromised mice also show a striking reduction in SVZ proliferation (supplemental Fig. 2b", available at www.jneurosci.org as supplemental material, see also Fig. $5 g$ ), whereas control mice do not (supplemental Fig. 2a", available at www.jneurosci.org as supplemental material) (see also Fig. 5f). The observation that controls (i.e., tamoxifen-treated Nestin ${ }^{\mathrm{CrEER} /+} ; \mathrm{Smo}^{\mathrm{cl+}}$; Rosa ${ }^{\text {stop LacZ/+ }}$ mice) were normal demonstrates that the phenotype we observed was a result of loss of Smo gene function. Moreover, these results combined with the absence of apoptosis in either our control or mutant mice demonstrate that tamoxifen-induced activity of CreER from our Nestin transgene is not toxic in this context.

As shown earlier by PCR genotyping of individual neurospheres, some wt cells remain in the SVZ after tamoxifen treatment of the Nestin ${ }^{\mathrm{CreER} /+}$; Smo ${ }^{c / c}$ animals (Fig. 5e). To ask whether these residual wt B cells could over time replenish the SVZ niche, we analyzed tamoxifen-treated Nestin ${ }^{\mathrm{CreER} /+} ; \mathrm{Smo}^{c / c}$ mice 10 months after the last injection of tamoxifen. Notably, we did not observe any recovery in SVZ proliferation in Nestin ${ }^{\mathrm{CreER} /+}$; Smo ${ }^{c / c}$ mice, or an increase in the numbers of $\beta-\mathrm{Gal}+$ cells (indicative of Glil expression) in $\mathrm{Nestin}^{\mathrm{CreER} /+}$; 
Adult Nestin ${ }^{\mathrm{CreERT} 2 /+} ;$ ROSa $^{\text {stop YFP/+ }}$
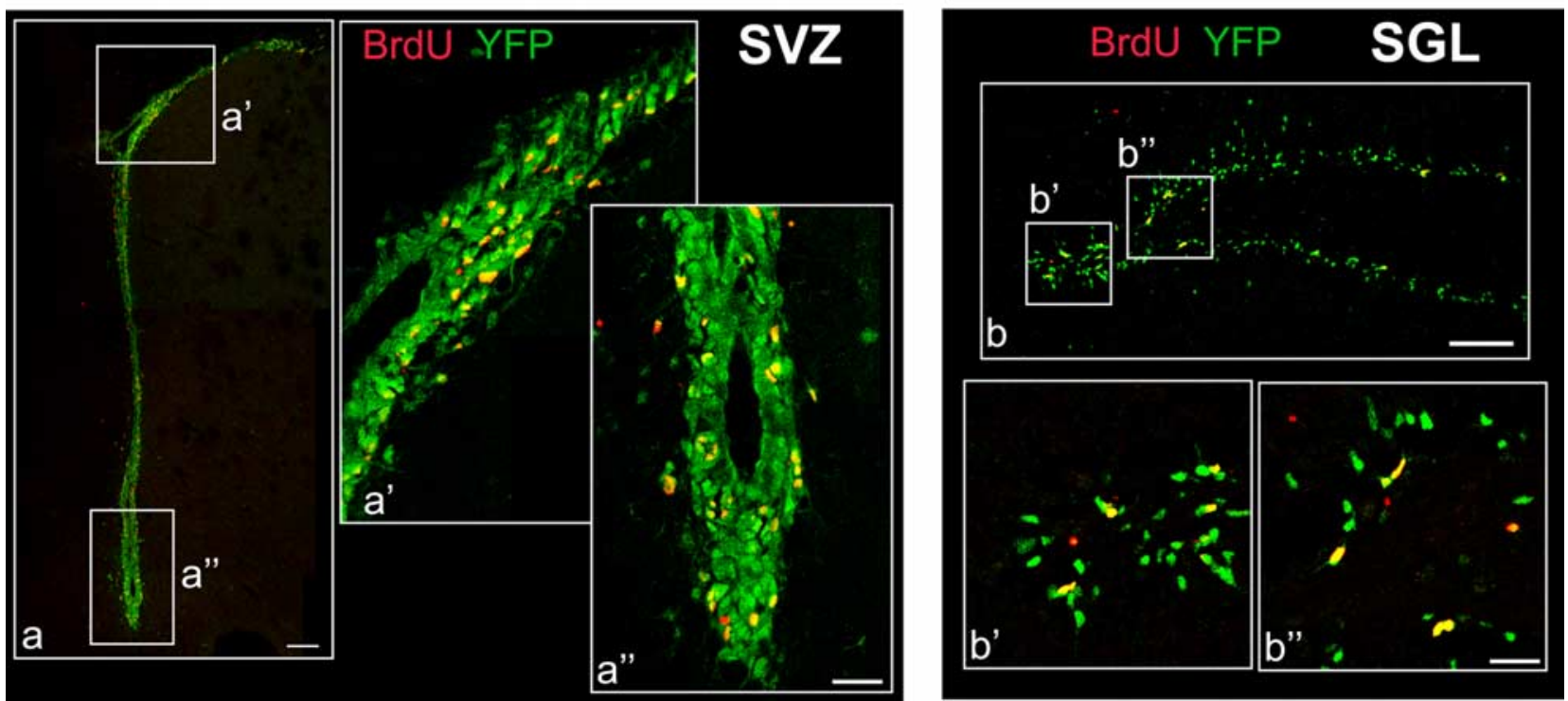

Figure 4. Cells undergoing Cre-induced recombination are proliferating cells, in the adult SVZ and SGL. $\boldsymbol{a}, \boldsymbol{b}$, Coronal views of the adult SVZ ( $\boldsymbol{a}$ ) and SGL ( $\boldsymbol{b}$ ) showing double labeling for BrdU (in red) and YFP (in green, detected by GFP antibody) in tamoxifen-treated Nestin ${ }^{\text {(reER/+ }}$; Rosa ${ }^{\text {stop YFP/+ }}$ mice. Scale bars: $\boldsymbol{a}, \boldsymbol{b}, 100 \mu \mathrm{m} ; \boldsymbol{a}^{\prime}-\boldsymbol{b}^{\prime \prime}, 25 \mu \mathrm{m}$.

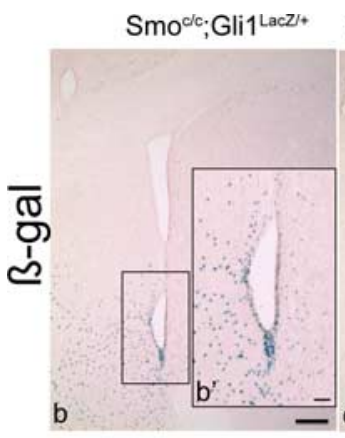

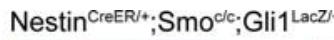
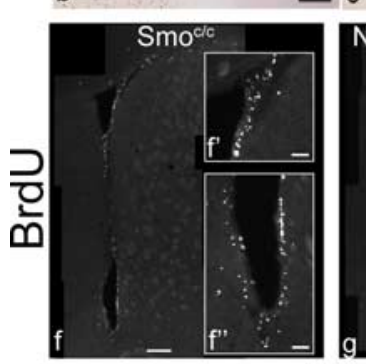

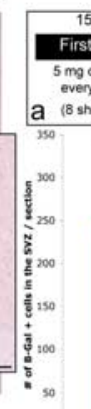

d

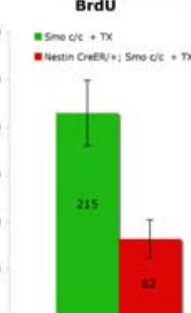

h.

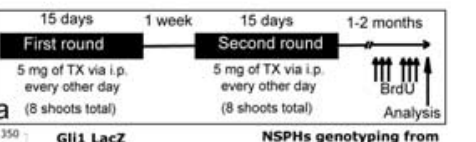

Gli1 LaCZ NSPHs genotyping from
Nestin

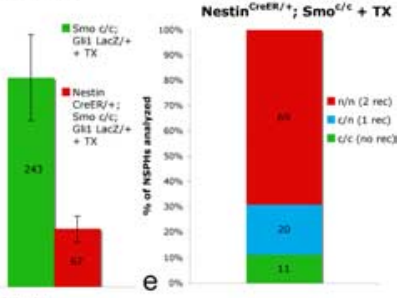

NEUROSPHERES

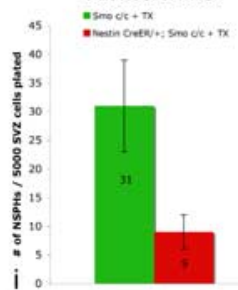

Figure 5. Loss of Hh signaling in tamoxifen-treated Nestin ${ }^{\mathrm{CreER}}$; Smo ${ }^{\mathrm{c} / \mathrm{c}}$ mice in the adult SVZ. $\boldsymbol{a}$, Diagram of the tamoxifen treatment the Nestin ${ }^{\text {(reER/+ }}$.Smo $0^{c / c}$ mice (ko) and Smo $0^{c / c}$ mice (controls) undergo, combined with the BrdU treatment. $\boldsymbol{b}, \boldsymbol{c}$ Coronal views of the adult SVZ showing $\beta$-Gal staining representing the expression pattern of the readout of Hh pathway, Gli1, in

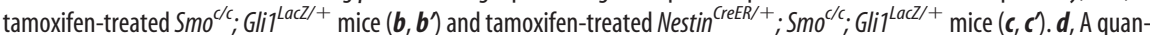
tification of the reduction in Gli1 expression in the SVZ. $e$, Results of PCR genotyping performed on individual neurospheres obtained from tamoxifen-treated Nestin ${ }^{C r e R /+} ; \mathrm{Smo}^{c / /}$ mice. Note that $\mathrm{n} / \mathrm{n}$ means that both events of recombination occurred; $\mathrm{c} / \mathrm{n}$ means that only one event of recombination occurred; $\mathrm{c} / \mathrm{c}$ indicate that no recombination occurred in the Smo conditional alleles. $\boldsymbol{f}, \boldsymbol{g}$, Coronal views of the adult SVZ showing BrdU-incorporating cells in tamoxifen-treated Smoc/c mice $\left(\boldsymbol{f}-\boldsymbol{f}^{\prime \prime}\right)$ and in tamoxifen-treated Nestin ${ }^{C r e E R /+} ;$ Smoc/c mice $\left(\boldsymbol{g}-\boldsymbol{g}^{\prime \prime}\right)$ soon after BrdU injections. $\boldsymbol{h}$, Quantification of the data shown in $\boldsymbol{f}$ and $\boldsymbol{g} . \boldsymbol{i}$, Quantification of the numbers of neurospheres generated from the SVZ of tamoxifen-treated Nestin ${ }^{\mathrm{CreER} /+} ; \mathrm{Smo}^{\mathrm{c} / \mathrm{c}}$ and controls. Scale bars: $\boldsymbol{b}, \boldsymbol{c}, 200 \mu \mathrm{m} ; \boldsymbol{b}^{\prime}, \boldsymbol{c}^{\prime}, 50 \mu \mathrm{m} ; \boldsymbol{f}, \boldsymbol{g}, 150 \mu \mathrm{m} ; \boldsymbol{f}^{\prime}, \boldsymbol{f}^{\prime \prime}, \boldsymbol{g}^{\prime}, \boldsymbol{g}^{\prime \prime}, 30 \mu \mathrm{m}$. Error bars represent SD. Statistics were performed by $t$ test, $p<0.05$. In $\boldsymbol{d}, \boldsymbol{h}, \boldsymbol{i}, \boldsymbol{n}=3$ animals each. In $\boldsymbol{e}, \mathrm{n}(\mathrm{NSPHs})=925,4$ animals.

$\mathrm{Smo}^{c / c}$; Gli1 ${ }^{\mathrm{LacZ} /+}$ mice (compare Fig. 5, supplemental Fig. 3, available at www.jneurosci.org as supplemental material). In addition, we again detected a reduction in the numbers of $\mathrm{C}, \mathrm{A}$ and B cells (compare Fig. 6, supplemental Fig. 4, available at www.

jneurosci.org as supplemental material). Together, these data suggest that the proliferation of SVZ progenitors, the production of new neuroblasts and the number of SVZ stem cells are impaired in the absence of Hh signaling, and that once Hh signaling is removed, the adult SVZ niche undergoes an irreversible collapse in terms of its ability to generate new neurons. Previous data however suggest that there may be a more trivial explanation for the long-term defects we observed in conditional Smo knock-out mice. It has been observed that in some circumstances, wt cells undergo Cre-mediated DNA damage (Loonstra et al., 2001). This then could explain their impaired capacity for self-renewal. However, this possibility is ruled out by the observation that the stem cell niche in our tamoxifen-treated $\mathrm{Smo}^{\mathrm{cl}+} ; \mathrm{Nestin}^{\mathrm{CreER}}$ control mice was unimpaired (supplemental Fig. 2a", available at www. jneurosci.org as supplemental material).

\section{Replenishment of the SVZ stem cell} niche is compromised in tamoxifentreated Nestin ${ }^{\mathrm{CreER} /+} ; \mathrm{Smo}^{c / c}$ mice after in vivo AraC treatment

A previous study (Ahn and Joyner, 2005), took advantage of a genetic fate mapping strategy (using a Gli1 ${ }^{\text {CreER }}$ driver line; Ahn and Joyner, 2004) that allowed the fate of Hh-responding cells to be followed and demonstrated that Gli1 + quiescent neural stem cells self-renew and generate multiple cell types in vivo. They also examined the fate of these cells in the context of an AraC infusion treatment, an antimitotic reagent that effectively kills fast-dividing cells in the SVZ while sparing 


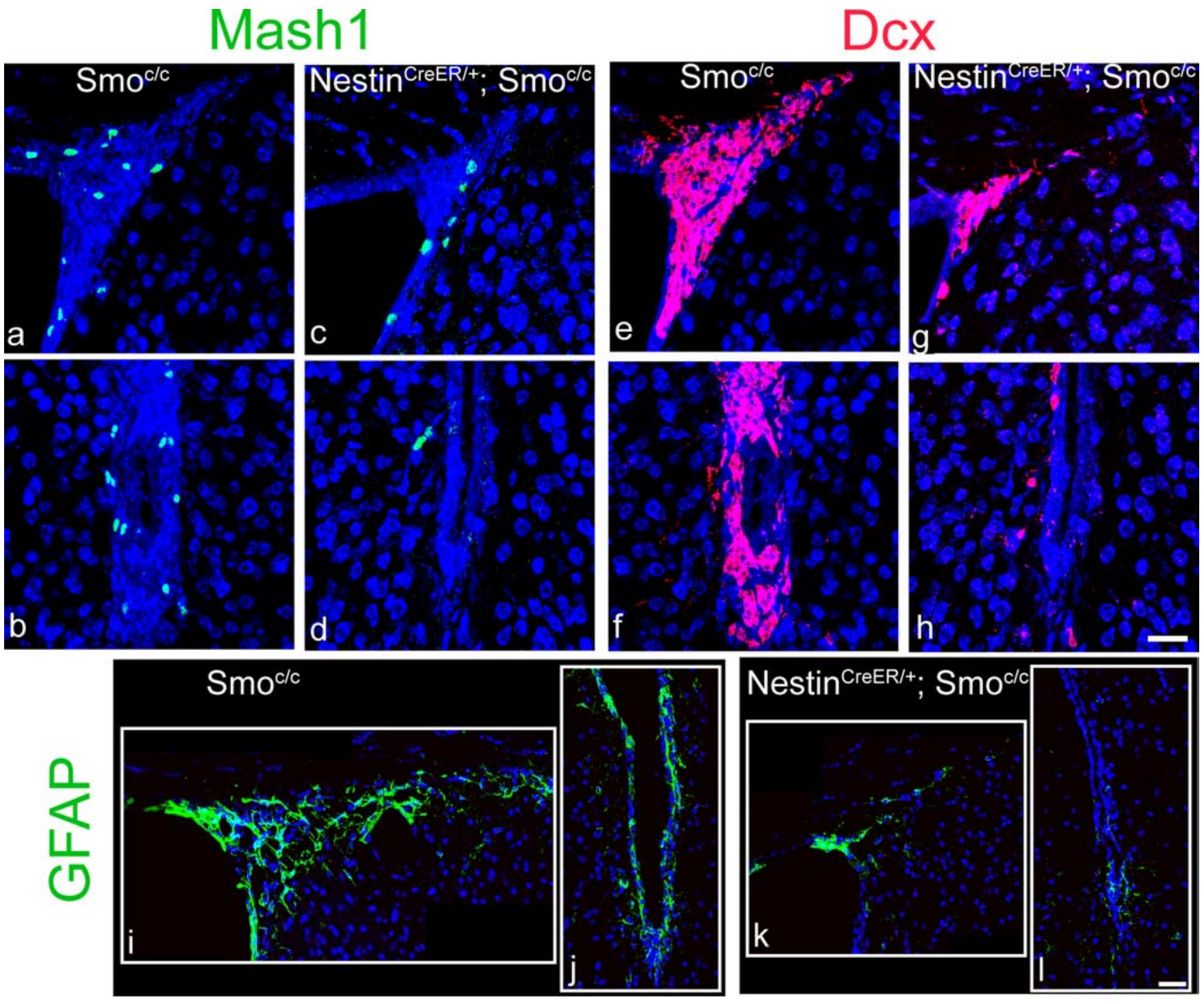

Figure 6. In tamoxifen-treated Nestin ${ }^{\text {CreER/+ }} ; S m 0^{c / c}$ mice compared with controls, all cells types in the SVZ lineage are affected. $\boldsymbol{a}-\boldsymbol{d}$, Coronal views of two areas of the SVZ (the dorsal and the ventral parts) showing Mash 1 immunostaining in tamoxifen-treated Smo $0^{c / c}$ mice $(\boldsymbol{a}, \boldsymbol{b})$ and in tamoxifen-treated Nestin ${ }^{(r e E R /+} ;$ Smo ${ }^{c / c}$ mice $(\boldsymbol{c}, \boldsymbol{d})$. Note that there is a $75 \%$ reduction in Mash1 expression. $\boldsymbol{e}-\boldsymbol{h}$, Coronal views of two areas of the SVZ showing Dcx immunostaining in tamoxifen-treated Smo ${ }^{c / c}$ mice $(\boldsymbol{e}, \boldsymbol{f})$ and in tamoxifen-treated Nestin ${ }^{C r e R /+} ;$; $m 0^{c / c}$ mice $(\boldsymbol{g}, \boldsymbol{h})$. Note that there is a $70 \%$ reduction in Dcx expression. $\boldsymbol{i}-\boldsymbol{I}$, Coronal views of two areas of the SVZ showing GFAP immunostaining in tamoxifen-treated Smo ${ }^{c / /}$ mice $(\boldsymbol{i}, \boldsymbol{j})$ and in tamoxifen-treated Nestin ${ }^{\text {CreER/+ }}$; Smo ${ }^{/ / /}$mice $(\boldsymbol{k}, \boldsymbol{I})$. Note that there is an $80 \%$ reduction in GFAP expression. Scale bars: (in $\left.\boldsymbol{h}\right) \boldsymbol{a}-\boldsymbol{j}, 30 \mu \mathrm{m}$; (in $\boldsymbol{I}$ ) $\boldsymbol{i} \boldsymbol{I}, 30 \mu \mathrm{m}$.

quiescent neural stem cells and postmitotic ependymal cells. They observed that Hh-responding (i.e., Gli1+) cells that survive AraC infusion treatment are rarely dividing neural stem cells and respond to this insult by increasing cell proliferation and the production of transit-amplifying cells (Ahn and Joyner, 2005). In this work, the authors however did not investigate whether this recovery was dependent on Hh signaling. To address this issue we examined whether this process of replenishment of the SVZ niche is altered in tamoxifen-treated Nestin ${ }^{\mathrm{CreER} /+} ; \mathrm{Smo}^{c / c}$ mice.

In our first set of control experiments, we performed AraC or saline treatment (Doetsch et al., 1999b) for $6 \mathrm{~d}$ on Gli1 $^{\text {LacZ/+ }}$ adult mice and analyzed the brains both soon after (time point referred to as $t=0$ ) and 1 week after pump removal (time point referred to as $t=7$ ) (supplemental Figs. $5 a, 6 a$, respectively, available at www.jneurosci.org as supplemental material). As expected, at $t=$ 0 we detected a marked $(70 \%)$ reduction in SVZ proliferation (supplemental Fig. 5b,d,e, available at www.jneurosci.org as supplemental material) coupled with a dramatic decrease $(80 \%)$ in the number of neurosphere forming cells (supplemental Fig. $5 c$ ). We also observed that Dcx immunostaining was almost absent in AraC treated animals (supplemental Fig. $5 f-i$ ). These observations confirmed that the osmotic pump treatment was successfully in ablating fast cycling cells $\mathrm{C}$ and A cells (Doetsch et al., 1999b). Interestingly, the LacZ staining (indicative of Gli1 expression) was not affected (supplemental Fig. $5 j, k$, available at www.jneurosci.org as supplemental material), confirming the notion that most of Glil expressing cells are slow cycling and thus resistant to antimitotic treatment (Ahn and Joyner, 2005). When we analyzed the animals at $t=7$ after 1 week of recovery time, we noticed that SVZ proliferation (supplemental Fig. 6b,d,e, available at www.jneurosci.org as supplemental material), number of neurospheres (supplemental Fig. $6 c$ ), and Dcx immunostaining (supplemental Fig. $6 f-i$ ) had returned to normal levels, suggesting that replenishment of the SVZ niche by the remaining B cells was effectively complete within a week of AraC treatment (Doetsch et al., 1999b). Notably, the number of $\beta$-Gal positive 

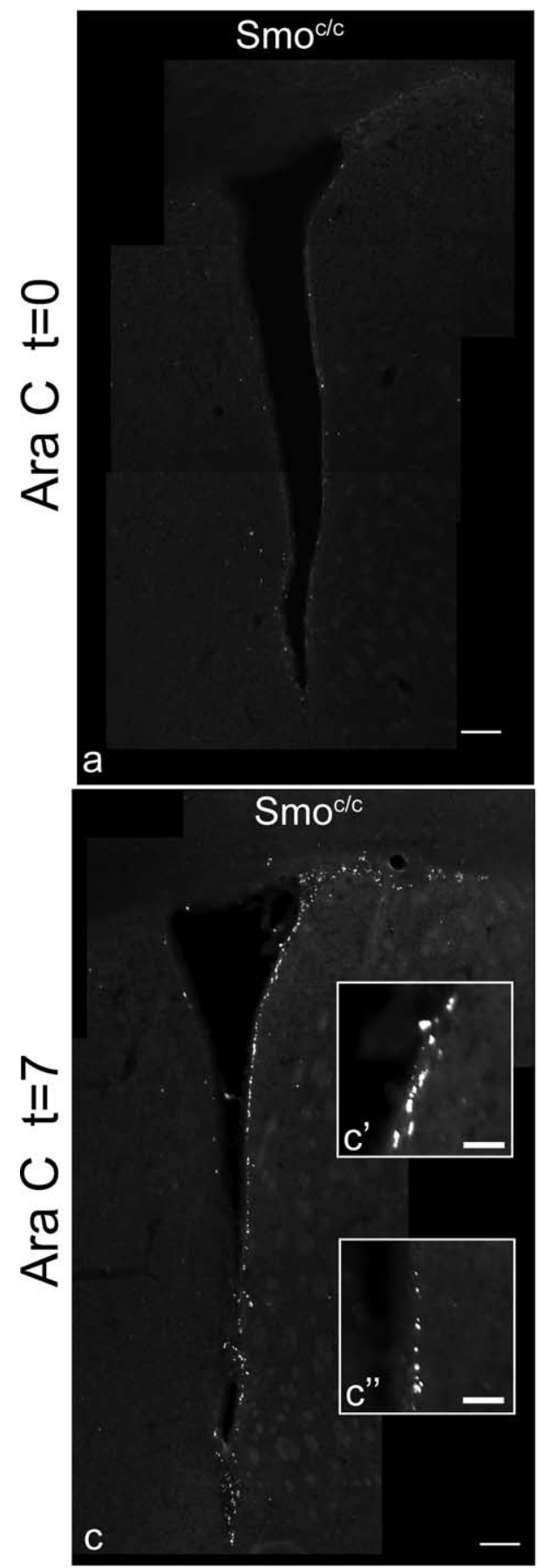
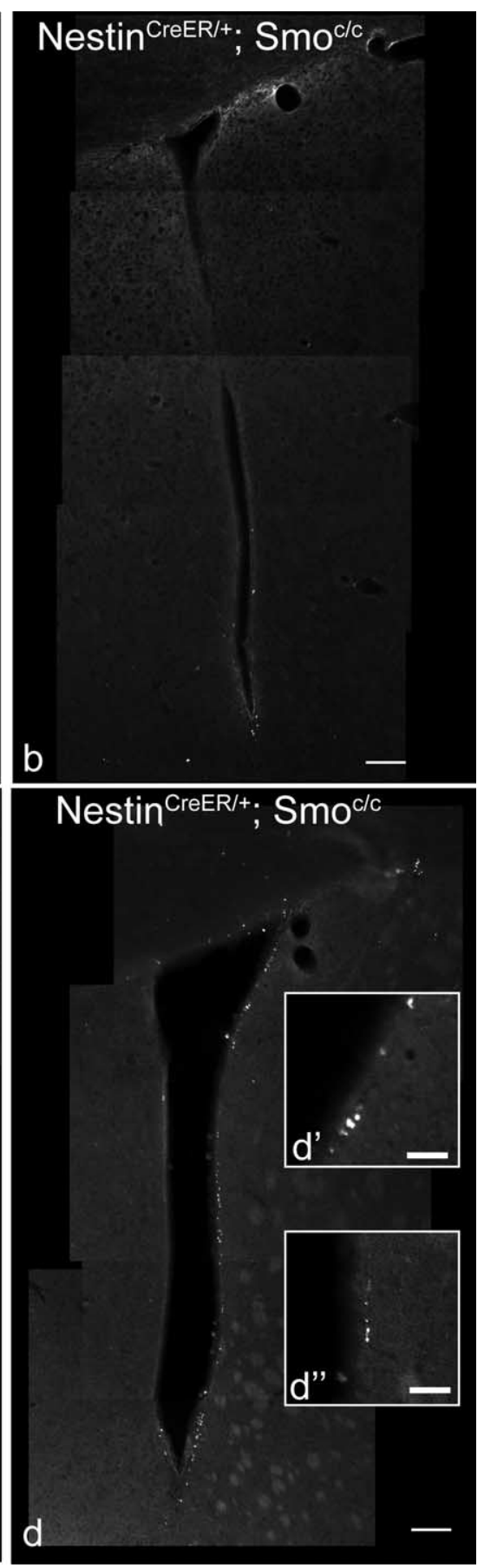

Figure 7. Partial replenishment of the SVZ stem cell niche in tamoxifen-treated Nestin ${ }^{\mathrm{CreER} /+} ; \mathrm{Smo}^{\mathrm{c} / \mathrm{c}}$ mice after AraC injury in vivo. $\boldsymbol{a}-\boldsymbol{d}$, Coronal views of the SVZ showing BrdU-incorporating cells soon after the removal of the pump $(t=0 ; \boldsymbol{a}, \boldsymbol{b})$ and 1 week after pump removal $(t=7 ; \boldsymbol{c}, \boldsymbol{d})$ in AraC-treated controls (tamoxifen-treated Smo ${ }^{c / c}$ mice; $\boldsymbol{a}, \boldsymbol{c}$ ) and AraC-treated ko animals (tamoxifen-treated Nestin ${ }^{\mathrm{CreER} /+} ;{ }_{\text {Smo }}{ }^{\mathrm{c} / \boldsymbol{c}}$ mice; $\left.\boldsymbol{b}, \boldsymbol{d}\right)$. Scale bars: $\boldsymbol{a}-\boldsymbol{d}, 100 \mu \mathrm{m} ; \boldsymbol{c}^{\prime}, \boldsymbol{c}^{\prime}, \boldsymbol{d}^{\prime}, \boldsymbol{d}^{\prime}, 30 \mu \mathrm{m}$.

cells (indicative for Glil expression) did not change compared with that observed before AraC treatment (supplemental Fig. $6 j, k$, available at www.jneurosci.org as supplemental material).

As described above, tamoxifen-treated Nestin ${ }^{\mathrm{CreER} /+} ; \mathrm{Smo}^{\mathrm{c} / \mathrm{c}}$ mice are characterized by a marked $(60 \%)$ decrease in proliferation in the SVZ (Fig. $5 f-h$ ) and a corresponding reduction in their ability to generate neurospheres (70\% reduction) (Fig. 5i). To test whether the spared SVZ progenitors were still able to replenish the SVZ niche after cessation of treatment with the antimitotic agent AraC, we challenged tamoxifen-treated
Nestin $^{\mathrm{CreER} /+} ; \mathrm{Smo}^{c / c}$ mice and tamoxifentreated $\mathrm{Smo}^{c / c}$ mice (controls) with the same antimitotic insult. Soon after the removal of the pump $(t=0)$, both AraCtreated controls and conditional Smo null animals show a marked reduction in the general level of proliferation (Figs. $7 a, b, 8 a$ ) and in their ability to generate neurospheres (Fig. 8b).

One week after pump removal $(t=7)$, both controls and conditional Smo null animals treated with $\mathrm{AraC}$ recover to the level of proliferation seen before the antimitotic insult (Figs. $7 c, d, 8 a$ ). Similarly, one week after AraC treatment, the ability of both mutant and control SVZ progenitors to generate neurospheres recovers to that seen before the antimitotic insult (Fig. 8b). However, the Smo conditional mice continue to show a decrease in SVZ proliferation (50\% reduction) and in the ability to generate neurospheres (55\% reduction), compared with the control group (i.e., tamoxifen-treated $S m o^{c / c}$ mice). In addition, we observed a $70 \%$ reduction in the number of Gli1 + cells in the SVZ of AraCtreated conditional Smo mutant mice (tamoxifen-treated Nestin ${ }^{\mathrm{CreER} /+}$; Smo ${ }^{c / c}$; Gli1 $^{\text {LacZ/+ }}$ ) compared with the control group (tamoxifen-treated $\mathrm{Smo}^{c / c}$; Gli1 ${ }^{\mathrm{LacZ} /+}$ mice that received AraC treatment) both at $t=0$ and $t=7$ (Fig. $8 \mathrm{c}$ ). These results mirror the difference observed in Gli1 + cells in wildtype versus mutant animals before AraC treatment $(t=-7)$ (Fig. 8c). Furthermore, Hh signaling remains extremely impaired in conditional Smo mice even after a recovery period of 1 month $(t=30)$ (Fig. $8 c$ ).

Together these data suggest that conditional Smo null animals are only partially able to replenish the niche, despite the residual presence of $\sim 30 \%$ wild-type B cells (i.e., cells that failed to excise the conditional Smo allele after tamoxifen treatment).

The self-renewal property of SVZ stem cells in vivo is affected by the loss of Hh signaling

We wished to test directly whether this partial recovery was mediated by the spared SVZ B cells $(\sim 30 \%)$ that did not undergo recombination of the conditional Smo locus $\left(S m o^{c / c}\right.$ and $\left.S m o^{c / n}\right)$. We performed PCR genotyping on individual neurospheres (NSPHs) generated from tamoxifen-treated Nestin ${ }^{\mathrm{CreER} /+} ; \mathrm{Smo}^{c / c}$ mice that received AraC treatment, at $t=0$ and $t=7$. We found that whereas soon after the removal of the pump the majority of the NSPHs were $S m o^{n / n}(62 \%)$, after 1 week of recovery the majority of the NSPHs are comprised by a combination of $S m o^{c / c}$ and $S m o^{c / n}$ and only $29 \%$ of NSPHs are $S m o^{n / n}$ (Fig. $8 d$ ).

This analysis suggests that the partial replenishment of the niche observed in conditional Smo null mice after AraC treat- 
ment is performed by those B cells that did not undergo recombination of the conditional Smo locus (Fig. 9). Collectively, the data suggest that the self-renewal property of SVZ stem cells in vivo is affected by the loss of Hh signaling during adulthood. Moreover, the remaining wild-type B cells cannot replace the lost $\mathrm{B}$ stem cell population.

\section{Discussion}

The present study examines the effects of the postnatal (P60) removal of Smo in the SVZ stem cell lineage. Having previously studied the consequences of embryonic (E12.5) removal of Hh signaling (Machold et al., 2003; Balordi and Fishell, 2007), we wished to examine whether a similar reduction in SVZ proliferation occurs after removal of Hh signaling only after animals have reached adulthood. The Nestin ${ }^{\mathrm{Cr} /+}$ transgenics (Tronche et al., 1999; GrausPorta et al., 2001) used in our previous studies removed Hh signaling soon after the initiation of neurogenesis. Thus, the reduction in neural stem cells in the SVZ, as well as the concomitant increase in apoptosis could be an indirect consequence of removing Smo, although embryonic neurogenesis is still ongoing. Specifically it could reflect a requirement for $\mathrm{Hh}$ signaling in the establishment of the adult stem cell niche rather than a direct role in adult neurogenesis per se. Our results demonstrate that the requirement for Hh signaling in both stem cell maintenance and transitamplifying cell proliferation is conserved throughout adulthood.

\section{Conditional removal of Smoothened gene} function using a Nestin ${ }^{\text {CreER }}$ driver

The advent of conditional null alleles combined with the availability of CreER, a tamoxifen-activated form of Cre, have lead to a large number of studies using these methods to remove gene function in a cell autonomous manner (Kuo et al., 2006). Although in principal straightforward, such studies come with considerable caveats that need to be considered in both the design and interpretation of experiments. First and foremost, it is essential that Cre-mediated recombination does not significantly occur in the absence of tamoxifen-activation of CreER. In the case of a transgenic such as the Nestin ${ }^{\text {CreER }}$ where expression of CreER persists for a prolonged period of time, the potential for nonregulated recombination, as well as the possible toxicity from the constitutive presence of CreER are concerns (Forni et al., 2006). The transgenic line we used in these experiments had an intermediate level of expression, as the strongest expressing line had a high degree of background recombination.

Even given the high degree of fidelity in expression of our Nestin ${ }^{\text {CreER }}$ transgene and the low degree of background recombination, it was essential to demonstrate that the adult SVZ niche was unimpaired. We observed normal proliferation in either noninduced Nestin ${ }^{C r e E R} ; S_{m o}{ }^{c / c}$ (supplemental Fig. 1e, available at
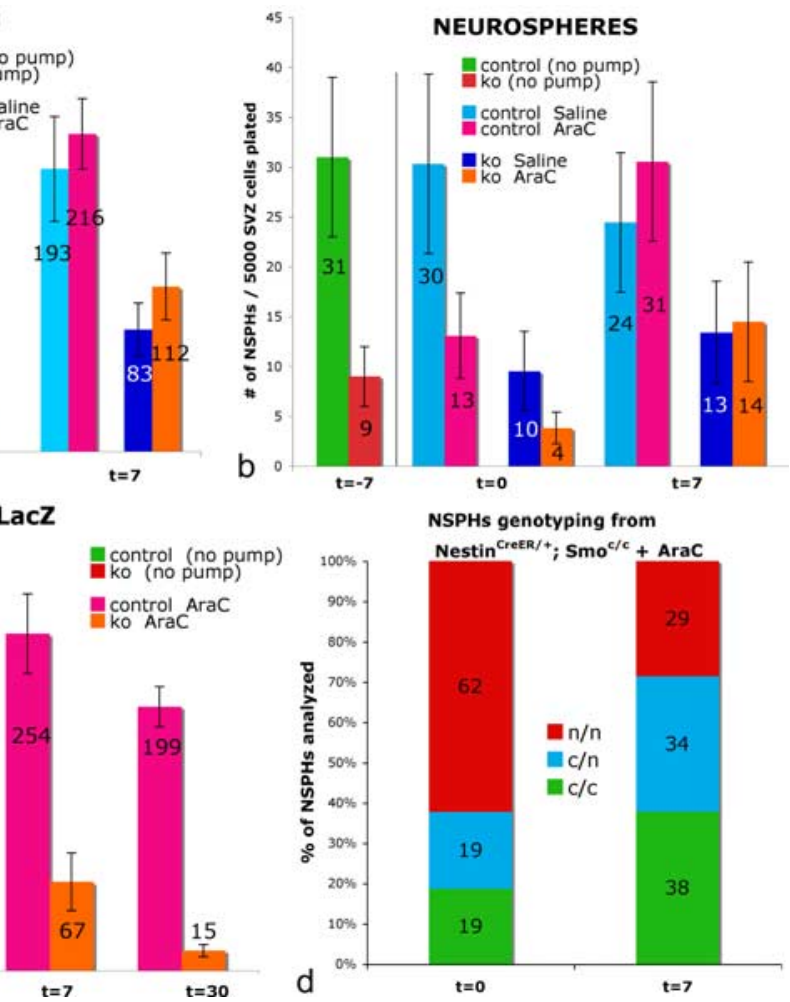

Figure 8. The partial replenishment of the SVZ stem cell niche in knock-out (ko) mice after AraC treatment is mainly per$\mathrm{Smo}^{\mathrm{c} / \mathrm{C}}$ ) and $\mathrm{ko}$ (tamoxifen-treated Nestin ${ }^{\mathrm{CreER} /+} ; \mathrm{Smo}^{\mathrm{c} / \mathrm{C}}$ ) animals before the implantation of the pump $(t=-7)$ in salinecontrols and ko, and in AraC-treated controls and ko, soon after the removal of the pump $(t=0)$ and 1 week after pump

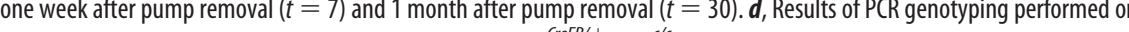

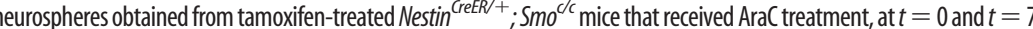
that no recombination occurred within the $S m 0$ conditional alles In all panels $t=-7$ means without pump $t=0$ means pump removal and $t=7$ means 1 week after pump removal. Error bars represent SD. Statistics were performed by $t$ test, $p<0.05$. In $\boldsymbol{a}-\boldsymbol{c}, n=3$ animals each; in $\boldsymbol{d}, t=0, \mathrm{n}(\mathrm{NSPHs})=480,3$ animals; $t=7, \mathrm{n}$ (NSPHs) $=405,3$ animals.

www.jneurosci.org as supplemental material) or tamoxifentreated Nestin ${ }^{\mathrm{CrER} /+} ; \mathrm{Smo}^{\mathrm{c/+}} ; \mathrm{Rosa}^{\text {stop LacZ/+ }}$ mice (supplemental Fig. $2 a$ ", available at www.jneurosci.org as supplemental material). Moreover, the numbers of $\beta$-Gal-expressing cells in noninduced Nestin ${ }^{\mathrm{CreER} /+}$; Smo ${ }^{c / c}$; Gli1 ${ }^{\mathrm{LacZ} /+}$ mice (supplemental Fig. $1 c$, available at www.jneurosci.org as supplemental material) and in tamoxifen-treated Nestin ${ }^{\mathrm{CrEER/+}} ; \mathrm{Smo}^{\mathrm{c/+}}$; Rosa ${ }^{\text {stop LacZ/+ }}$ mice (supplemental Fig. $2 a$, available at www.jneurosci.org as supplemental material) was comparable with that seen in wild-type mice. This indicates that neither the background level of recombination of the Smo locus that is likely occurring in noninduced $\mathrm{Nestin}^{\mathrm{CreER}} ; \mathrm{Smo}^{c / c}$ mice, or a possible tamoxifen-mediated toxicity of the CreER expressed from the Nestin ${ }^{\mathrm{CreER} /+}$ transgenics is sufficient in itself to perturb the adult SVZ neurogenic niche.

\section{Hedgehog signaling is required for B cell maintenance in the adult SVZ}

Another group (Palma et al., 2005) previously addressed the requirement for Hh signaling in the adult SVZ niche using a pharmacological approach based on systemic injections of cyclopam- 


\section{TX treated-Nestin ${ }^{\mathrm{CreER} /+} ; \mathrm{Smo}^{\mathrm{clc}}$ mice after AraC challenge}

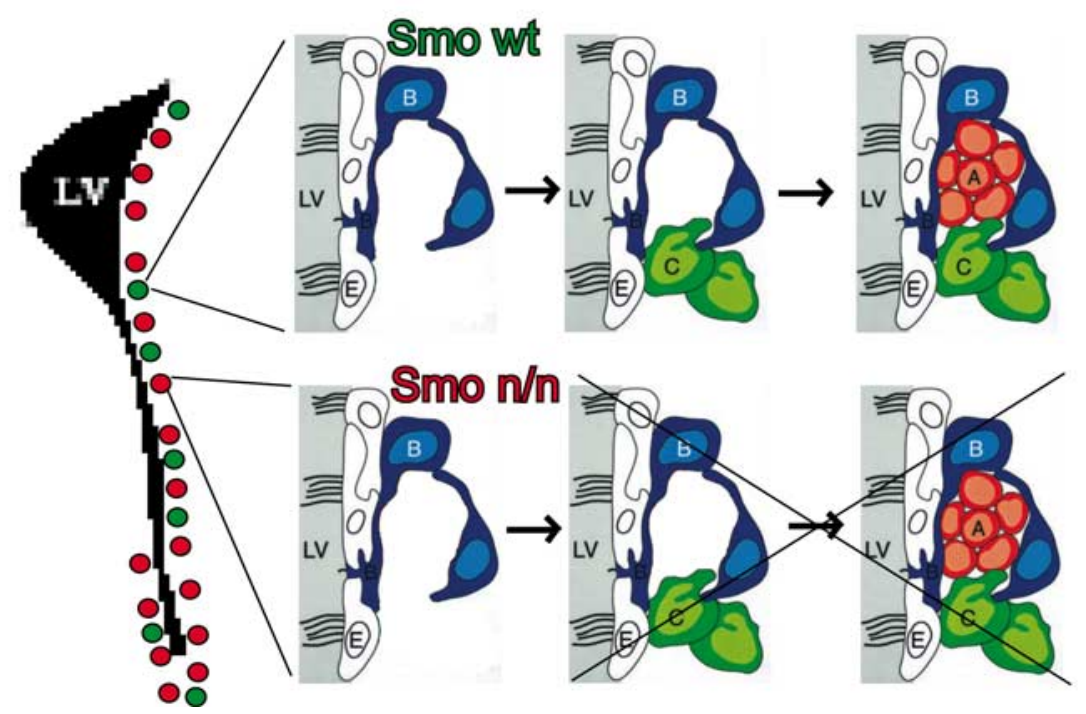

Figure 9. The self-renewal property of SVZ stem cells in vivo is affected by the loss of Hh signaling. In tamoxifen-treated Nestin ${ }^{\mathrm{CreER} /+} ; \mathrm{Smo}^{\mathrm{c} / \mathrm{c}}$ mice, $\sim 70 \%$ of SVZ progenitors are $S m 0^{n / n}$, whereas $30 \%$ are not fully knocked out $\left(\mathrm{Smo}^{c / c}\right.$ and $S m 0^{c / n}$ ), according to the NSPHs PCR genotyping shown in Figure $5 e$. After the AraC injury, the $S m 0^{n / n} B$ cells are not able to self-renew, whereas the spared wt B cells $\left(S m o^{c / c}\right.$ and $\left.S m o^{c / n}\right)$ can self-renew but are not able to make up for the entire SVZ, suggesting that they might be competent to regenerate only a small local portion of SVZ. Adapted from Doetsch et al. (1999) with permission from Alvarez-Buylla.

ine, an $\mathrm{Hh}$ signaling inhibitor. This study showed that cyclopamine treatment results in a marked (50\%) decrease of BrdU incorporation in the SVZ. However, this analysis had to be performed soon after the cyclopamine treatment, because of the short-term effect of the pharmacological treatment. This precluded any determination of whether there is an adult requirement for Hh signaling beyond simply acting as a mitogen. The genetic approach we undertook allowed us to irreversibly knock out Hh signaling in the adult brain and subsequently monitor the effects on the SVZ throughout the mouse's life. Our experiments extended our previous findings (Balordi and Fishell, 2007) by definitively demonstrating in the adult that the maintenance of $B$ cells in the SVZ requires ongoing Hh signaling. Specifically, our work argues that the persistence of B cells in the adult SVZ stem cell niche is compromised when they are unable to respond to $\mathrm{Hh}$ signaling.

\section{Loss of hedgehog signaling permanently impairs the adult stem cell niche}

When we administered tamoxifen to adult $\mathrm{Nestin}^{\mathrm{CreER} /+}$; Smo ${ }^{\mathrm{c} / \mathrm{c}}$ mice, we successfully removed Smo in $\sim 70 \%$ of the SVZ progenitors, as assessed by genotyping neurospheres derived from these animals (Fig. 5e). However, it seems probable that our success in removing the Smo locus from these animals was likely closer to $95 \%$. We conclude this based on both our present and previous observation (Machold et al., 2003) that $\mathrm{Smo}^{-1-}$ SVZ cells form neurospheres at consistently $15 \%$ the efficiency of wild-type SVZ cells [Machold et al. (2003), their Fig. 8C]. Hence, it seems likely that the remaining wild-type neurospheres are six times over represented in our cultures.

The acute reduction in proliferation observed in the SVZ of mice where Smo gene function has been removed does not improve over time. We found that neurogenesis in the SVZ of Nestin ${ }^{\mathrm{CreER} /+}$; Smo ${ }^{c / c}$ mice is significantly impaired even 10 months after the last tamoxifen injection (supplemental Figs. 3, 4, available at www.jneurosci.org as supplemental material). Of particular interest is the observation that GFAP + cells are still extremely impaired in long-term Smo conditional knock-outs (supplemental Fig. 4j, available at www.jneurosci.org as supplemental material). This suggests that the few spared wild-type SVZ progenitors are incapable of producing de novo $\mathrm{B}$ cells (i.e., selfrenew) to repopulate the adult SVZ niche.

Previous work by Doetsch et al. (1999b) demonstrated that, after antimitotic treatment, the stem cell niche is quickly replenished. That Hh-responsive B cells are activated in this context was dramatically shown in a previous study from the Joyner laboratory (Ahn and Joyner, 2005). They demonstrate that Hh-responsive (Gli1+) quiescent neural stem cells self-renew, generate multiple cell types in vivo and respond to the AraC insult by increasing cell proliferation (Ahn and Joyner, 2005). We wished to examine whether the removal of Hhresponsiveness in the majority of $\mathrm{B}$ cells compromises this process or rather if the residual wild-type $B$ cells can react by replenishing the niche after an antimitotic insult.

We challenged tamoxifen-treated Nestin ${ }^{\mathrm{CrEER} /+} ; \mathrm{Smo}^{c / c}$ and control mice with AraC. As expected, after immediate withdrawn of the drug, the SVZ of both mutant and control mice was extremely impaired, in terms of general level of proliferation and ability to generate neurospheres. Furthermore, control mice (tamoxifen-treated $\mathrm{Smo}^{c / c}$ mice) that underwent AraC infusion showed a full recovery similar to a wild-type niche. In contrast, mice in which the SVZ is depleted of Smo gene function (i.e., tamoxifen-treated $\mathrm{Nestin}^{\mathrm{CreER} /+}$; Smo ${ }^{c / c}$ mice) were only able to replenish the SVZ niche to the level observed before AraC treatment (Fig. $8 a-c$ ). Moreover, by PCR genotyping of individual neurospheres, we demonstrate that this partial recovery is predominantly performed by the spared SVZ progenitors that did not undergo complete recombination of the conditional Smo allele (Fig. 8d). Interestingly, these data demonstrate that the few spared wild-type B cells (i.e., $S m o^{c / c}$ and $S m o^{c / n}$ ) are not able to replenish the entire $S V Z$ after the AraC injury. This suggests that their ability to generate new SVZ B cells is limited, possibly because they are only competent to replenish B cells in their immediate vicinity. This observation is reminiscent of the previous findings that postnatal neural stem cells are a restricted and diverse population of progenitors, with different regions producing specific OB interneuron subtypes (Merkle et al., 2007, Young et al., 2007). Hence, the mosaic organization of progenitors within the SVZ may reflect their inherent lineage restriction. Indeed, it would be interesting to examine whether $\mathrm{Hh}$ signaling has a role in maintaining the entire diversity of $\mathrm{OB}$ interneurons generated postnatally or only specific subtypes, a possibility we are currently exploring. It remains possible that in our experiments the ability for stem cell self-renewal is compromised because of a requirement for hedgehog signaling in the niche itself (Ha et al., 2002; Aihara et al., 2004). Hence, another possibility worth exploring is whether the failure we observe in stem cell self-renewal is a result of Smo being deleted in stromal components of the stem cell niche (e.g., nestin-positive endothelial cells). These consider- 
ations aside, our work demonstrates that self-renewal in the SVZ niche is affected by the loss of Hh signaling in vivo. This suggests a marked rethinking of the nature of the adult stem cell niche. Our findings suggest that postnatal B cells are both limited in number and in their ability to symmetrically divide to repopulate the adult niche.

\section{References}

Ahn S, Joyner AL (2004) Dynamic changes in the response of cells to positive hedgehog signaling during mouse limb patterning. Cell 118:505-516.

Ahn S, Joyner AL (2005) In vivo analysis of quiescent adult neural stem cells responding to Sonic hedgehog. Nature 437:894-897.

Aihara M, Sugawara K, Torii S, Hosaka M, Kurihara H, Saito N, Takeuchi T (2004) Angiogenic endothelium-specific nestin expression is enhanced by the first intron of the nestin gene. Lab Invest 84:1581-1592.

Altman J (1969) Autoradiographic and histological studies of postnatal neurogenesis. IV. Cell proliferation and migration in the anterior forebrain, with special reference to persisting neurogenesis in the olfactory bulb. J Comp Neurol 137:433-457.

Bai CB, Auerbach W, Lee JS, Stephen D, Joyner AL (2002) Gli2, but not Gli1, is required for initial Shh signaling and ectopic activation of the Shh pathway. Development 129:4753-4761.

Bai CB, Stephen D, Joyner AL (2004) All mouse ventral spinal cord patterning by hedgehog is Gli dependent and involves an activator function of Gli3. Dev Cell 6:103-115.

Balordi F, Fishell G (2007) Hedgehog signaling in the subventricular zone is required for both the maintenance of stem cells and the migration of newborn neurons. J Neurosci 27:5936-5947.

Britto J, Tannahill D, Keynes R (2002) A critical role for sonic hedgehog signaling in the early expansion of the developing brain. Nat Neurosci 5:103-110.

Brown JP, Couillard-Despres S, Cooper-Kuhn CM, Winkler J, Aigner L, Kuhn HG (2003) Transient expression of doublecortin during adult neurogenesis. J Comp Neurol 467:1-10.

Chiang C, Litingtung Y, Lee E, Young KE, Corden JL, Westphal H, Beachy PA (1996) Cyclopia and defective axial patterning in mice lacking Sonic hedgehog gene function. Nature 383:407-413.

Chiasson BJ, Tropepe V, Morshead CM, van der Kooy D (1999) Adult mammalian forebrain ependymal and subependymal cells demonstrate proliferative potential, but only subependymal cells have neural stem cell characteristics. J Neurosci 19:4462-4471.

Dahmane N, Ruiz i Altaba A (1999) Sonic hedgehog regulates the growth and patterning of the cerebellum. Development 126:3089-3100.

Doetsch F, Garcia-Verdugo JM, Alvarez-Buylla A (1997) Cellular composition and three-dimensional organization of the subventricular germinal zone in the adult mammalian brain. J Neurosci 17:5046-5061.

Doetsch F, Caille I, Lim DA, Garcia-Verdugo JM, Alvarez-Buylla A (1999a) Subventricular zone astrocytes are neural stem cells in the adult mammalian brain. Cell 97:703-716.

Doetsch F, Garcia-Verdugo JM, Alvarez-Buylla A (1999b) Regeneration of a germinal layer in the adult mammalian brain. Proc Natl Acad Sci USA 96:11619-11624.

Doetsch F, Petreanu L, Caille I, Garcia-Verdugo JM, Alvarez-Buylla A (2002) EGF converts transit-amplifying neurogenic precursors in the adult brain into multipotent stem cells. Neuron 36:1021-1034.

Echelard Y, Epstein DJ, St-Jacques B, Shen L, Mohler J, McMahon JA, McMahon AP (1993) Sonic hedgehog, a member of a family of putative signaling molecules, is implicated in the regulation of CNS polarity. Cell 75:1417-1430.

Englund U, Bjorklund A, Wictorin K (2002) Migration patterns and phenotypic differentiation of long-term expanded human neural progenitor cells after transplantation into the adult rat brain. Brain Res Dev Brain Res 134:123-141.

Ericson J, Muhr J, Placzek M, Lints T, Jessell TM, Edlund T (1995) Sonic hedgehog induces the differentiation of ventral forebrain neurons: a common signal for ventral patterning within the neural tube. Cell 81:747-756.

Feil R, Wagner J, Metzger D, Chambon P (1997) Regulation of Cre recombinase activity by mutated estrogen receptor ligand-binding domains. Biochem Biophys Res Commun 237:752-757.

Forni PE, Scuoppo C, Imayoshi I, Taulli R, Dastru W, Sala V, Betz UA, Muzzi P, Martinuzzi D, Vercelli AE, Kageyama R, Ponzetto C (2006) High levels of Cre expression in neuronal progenitors cause defects in brain de- velopment leading to microencephaly and hydrocephaly. J Neurosci 26:9593-9602.

Francis F, Koulakoff A, Boucher D, Chafey P, Schaar B, Vinet MC, Friocourt G, McDonnell N, Reiner O, Kahn A, McConnell SK, Berwald-Netter Y, Denoulet P, Chelly J (1999) Doublecortin is a developmentally regulated, microtubule-associated protein expressed in migrating and differentiating neurons. Neuron 23:247-256.

Fuccillo M, Rallu M, McMahon AP, Fishell G (2004) Temporal requirement for hedgehog signaling in ventral telencephalic patterning. Development 131:5031-5040.

Fuccillo M, Joyner AL, Fishell G (2006) Morphogen to mitogen: the multiple roles of Hedgehog signaling in vertebrate neural development. Nat Rev Neurosci 7:772-783.

Gleeson JG, Lin PT, Flanagan LA, Walsh CA (1999) Doublecortin is a microtubule-associated protein and is expressed widely by migrating neurons. Neuron 23:257-271.

Graus-Porta D, Blaess S, Senften M, Littlewood-Evans A, Damsky C, Huang Z, Orban P, Klein R, Schittny JC, Muller U (2001) Betal-class integrins regulate the development of laminae and folia in the cerebral and cerebellar cortex. Neuron 31:367-379.

Ha Y, Choi JU, Yoon DH, Cho YE, Kim TS (2002) Nestin and small heat shock protein expression on reactive astrocytes and endothelial cells in cerebral abscess. Neurosci Res 44:207-212.

Ingham PW, McMahon AP (2001) Hedgehog signaling in animal development: paradigms and principles. Genes Dev 15:3059-3087.

Kohtz JD, Baker DP, Corte G, Fishell G (1998) Regionalization within the mammalian telencephalon is mediated by changes in responsiveness to Sonic Hedgehog. Development 125:5079-5089.

Kuo CT, Mirzadeh Z, Soriano-Navarro M, Rasin M, Wang D, Shen J, Sestan N, Garcia-Verdugo J, Alvarez-Buylla A, Jan LY, Jan YN (2006) Postnatal deletion of Numb/Numblike reveals repair and remodeling capacity in the subventricular neurogenic niche. Cell 127:1253-1264.

Lai K, Kaspar BK, Gage FH, Schaffer DV (2003) Sonic hedgehog regulates adult neural progenitor proliferation in vitro and in vivo. Nat Neurosci 6:21-27.

Lee J, Platt KA, Censullo P, Ruiz i Altaba A (1997) Gli1 is a target of Sonic hedgehog that induces ventral neural tube development. Development 124:2537-2552.

Lewis PM, Dunn MP, McMahon JA, Logan M, Martin JF, St-Jacques B, McMahon AP (2001) Cholesterol modification of sonic hedgehog is required for long-range signaling activity and effective modulation of signaling by Ptc1. Cell 105:599-612.

Lois C, Alvarez-Buylla A (1994) Long-distance neuronal migration in the adult mammalian brain. Science 264:1145-1148.

Lois C, Garcia-Verdugo JM, Alvarez-Buylla A (1996) Chain migration of neuronal precursors. Science 271:978-981.

Long F, Zhang XM, Karp S, Yang Y, McMahon AP (2001) Genetic manipulation of hedgehog signaling in the endochondral skeleton reveals a direct role in the regulation of chondrocyte proliferation. Development 128:5099-5108.

Loonstra A, Vooijs M, Beverloo HB, Allak BA, van Drunen E, Kanaar R, Berns A, Jonkers J (2001) Growth inhibition and DNA damage induced by Cre recombinase in mammalian cells. Proc Natl Acad Sci USA 98:9209-9214.

Machold R, Hayashi S, Rutlin M, Muzumdar MD, Nery S, Corbin JG, GritliLinde A, Dellovade T, Porter JA, Rubin LL, Dudek H, McMahon AP, Fishell G (2003) Sonic hedgehog is required for progenitor cell maintenance in telencephalic stem cell niches. Neuron 39:937-950.

Markakis EA, Gage FH (1999) Adult-generated neurons in the dentate gyrus send axonal projections to field CA3 and are surrounded by synaptic vesicles. J Comp Neurol 406:449-460.

Marti E, Bumcrot DA, Takada R, McMahon AP (1995) Requirement of 19K form of Sonic hedgehog for induction of distinct ventral cell types in CNS explants. Nature 375:322-325.

Martinez-Cerdeno V, Noctor SC, Kriegstein AR (2006) Estradiol stimulates progenitor cell division in the ventricular and subventricular zones of the embryonic neocortex. Eur J Neurosci 24:3475-3488.

McMahon AP, Ingham PW, Tabin CJ (2003) Developmental roles and clinical significance of hedgehog signaling. Curr Top Dev Biol 53:1-114.

Merkle FT, Mirzadeh Z, Alvarez-Buylla A (2007) Mosaic organization of neural stem cells in the adult brain. Science 317:381-384.

Palma V, Lim DA, Dahmane N, Sanchez P, Brionne TC, Herzberg CD, Gitton Y, Carleton A, Alvarez-Buylla A, Ruiz i Altaba A (2005) Sonic hedgehog 
controls stem cell behavior in the postnatal and adult brain. Development 132:335-344.

Parras CM, Galli R, Britz O, Soares S, Galichet C, Battiste J, Johnson JE, Nakafuku M, Vescovi A, Guillemot F (2004) Mash1 specifies neurons and oligodendrocytes in the postnatal brain. EMBO J 23:4495-4505.

Rallu M, Machold R, Gaiano N, Corbin JG, McMahon AP, Fishell G (2002) Dorsoventral patterning is established in the telencephalon of mutants lacking both Gli3 and Hedgehog signaling. Development 129:4963-4974.

Reynolds BA, Weiss S (1992) Generation of neurons and astrocytes from isolated cells of the adult mammalian central nervous system. Science 255:1707-1710.

Rowitch DH, B SJ, Lee SM, Flax JD, Snyder EY, McMahon AP (1999) Sonic hedgehog regulates proliferation and inhibits differentiation of CNS precursor cells. J Neurosci 19:8954-8965.

Soriano P (1999) Generalized lacZ expression with the ROSA26 Cre reporter strain. Nat Genet 21:70-71.

Srinivas S, Watanabe T, Lin CS, William CM, Tanabe Y, Jessell TM, Costantini F (2001) Cre reporter strains produced by targeted insertion of EYFP and ECFP into the ROSA26 locus. BMC Dev Biol 1:4.

Stanfield BB, Trice JE (1988) Evidence that granule cells generated in the dentate gyrus of adult rats extend axonal projections. Exp Brain Res 72:399-406.

Tronche F, Kellendonk C, Kretz O, Gass P, Anlag K, Orban PC, Bock R, Klein
R, Schutz G (1999) Disruption of the glucocorticoid receptor gene in the nervous system results in reduced anxiety. Nat Genet 23:99-103.

Wallace VA (1999) Purkinje-cell-derived Sonic hedgehog regulates granule neuron precursor cell proliferation in the developing mouse cerebellum. Curr Biol 9:445-448.

Wechsler-Reya RJ, Scott MP (1999) Control of neuronal precursor proliferation in the cerebellum by Sonic Hedgehog. Neuron 22:103-114.

Wilkinson DG, Nieto MA (1993) Detection of messenger RNA by in situ hybridization to tissue sections and whole mounts. Methods Enzymol 225:361-373.

Yang HK, Sundholm-Peters NL, Goings GE, Walker AS, Hyland K, Szele FG (2004) Distribution of doublecortin expressing cells near the lateral ventricles in the adult mouse brain. J Neurosci Res 76:282-295.

Young KM, Fogarty M, Kessaris N, Richardson WD (2007) Subventricular zone stem cells are heterogeneous with respect to their embryonic origins and neurogenic fates in the adult olfactory bulb. J Neurosci $27: 8286-8296$.

Zhang XM, Ramalho-Santos M, McMahon AP (2001) Smoothened mutants reveal redundant roles for Shh and Ihh signaling including regulation of L/R asymmetry by the mouse node. Cell 105:781-792.

Zimmerman L, Parr B, Lendahl U, Cunningham M, McKay R, Gavin B, Mann J, Vassileva G, McMahon A (1994) Independent regulatory elements in the nestin gene direct transgene expression to neural stem cells or muscle precursors. Neuron 12:11-24. 